\title{
RELATIVE TIMING OF ALBITIZATION AND CHLORINE ENRICHMENT IN BIOTITE IN PROTEROZOIC SCHISTS, SNAKE CREEK ANTICLINE, MOUNT ISA INLIER, NORTHEASTERN AUSTRALIA
}

\author{
MichaEl J. RUBENACH \\ School of Earth Sciences, James Cook University, Townsville, 4811, Australia
}

\begin{abstract}
In the Snake Creek area, near Cloncurry, Mount Isa Inlier, in northeastern Australia, multiple episodes of deformation, lowpressure metamorphism, intrusion of abundant mafic and granitic bodies, and extensive metasomatism occurred throughout the Mesoproterozoic Isan Orogeny. Albitites and associated metasomatic biotite-rich schists are abundant in the core of the Snake Creek Anticline, and are concentrated in five areas. Albitization peaked during $\mathrm{D}_{1}$ and was commonly localized along shear zones. Muscovite schists adjacent to albitites were altered to albite-bearing biotite-rich schists. Porphyroblast growth in metasomatic rocks commenced with cordierite and andalusite from late syn- $\mathrm{D}_{1}$, but episodic growth continued to post- $\mathrm{D}_{5}$, with the peak of metamorphism occurring late syn- $\mathrm{D}_{3}$ to early syn- $\mathrm{D}_{4}$. The timing of albitization was determined from the presence or absence of albite in various stages of andalusite growth, and similarly the $\mathrm{Mg} \#[\mathrm{Mg} /(\mathrm{Mg}+\mathrm{Fe})]$ and $\mathrm{Cl}$ contents of biotite were examined over the span of porphyroblast-growth history. Differential mass-transport of $\mathrm{Mg}$ and Fe took place from the albitites to the adjacent schists predominantly during $\mathrm{D}_{1}$, and the $\mathrm{Mg}$ \# for biotite in metasomatic rocks was largely fixed during $\mathrm{D}_{1}$. The $\mathrm{Cl}$ content of the matrix biotite varies considerably in the different areas of albitite development, from below detection to a maximum of $1.5 \mathrm{wt} \%$. This could indicate that the $\mathrm{Cl}$ enrichment event was not related to albitization, but there is nevertheless an overall spatial relationship between them. In any particular sample, the $\mathrm{Cl}$ content in biotite is generally higher in the matrix than for inclusions in late andalusite, with inclusions in early andalusite being the poorest in $\mathrm{Cl}$. Enrichment of $\mathrm{Cl}$ in biotite is a function of $f(\mathrm{HCl}) / f\left(\mathrm{H}_{2} \mathrm{O}\right)$ rather than salinity, and so could be related to the replacement of muscovite by albite, as this involves release of $\mathrm{H}^{+}$. The ratio $f(\mathrm{HCl}) / f\left(\mathrm{H}_{2} \mathrm{O}\right)$ would have been low during periods of high flux of fluid that produced the albitites, but increased during low flux, in the waning stages of albitization, resulting in maximum enrichment in $\mathrm{Cl}$ relatively late in the metasomatic history.
\end{abstract}

Keywords: andalusite, metasomatism, albitization, biotite, $\mathrm{Cl}$ enrichment, Cloncurry area, Australia.

\section{SOMMAIRE}

De multiples épisodes de déformation, de métamorphisme à faible pression, d'intrusion de magmas abondants mafique et granitique, et de métasomatose répandue ont eu lieu tout au long de l'orogenèse Isanne, d'âge mésoprotérozoıque, dans la région de Snake Creek, près de Cloncurry, socle de Mount Isa, dans le nord-est de l'Australie. Les albitites et les schistes enrichis en biotite lors d'une métasomatose sont abondants au centre de l'anticlinal de Snake Creek, et sont surtout développés à cinq endroits. L'albitisation a atteint son développement maximum au cours de l'événement $\mathrm{D}_{1}$, surtout le long de zones de cisaillement. Les schistes à muscovite voisins des albitites ont été altérés à des schistes à biotite et à albite. La croissance des porphyroblastes dans les roches métasomatiques a commencé avec la cordiérite et l'andalousite à partir du stade $\mathrm{D}_{1}$ tardif, mais la croissance épisodique a continué au delà de $\mathrm{D}_{5}$, le paroxysme du métamorphisme ayant lieu soit tard au cours de l'événement $\mathrm{D}_{3}$, soit au début de l'événement $\mathrm{D}_{4}$. Le déroulement relatif de l'albitisation dans le temps a été déterminé par la présence ou absence de l'albite aux divers stades de croissance de l'andalousite, de même qu'en fonction du rapport $\mathrm{Mg} \#[\mathrm{Mg} /(\mathrm{Mg}+\mathrm{Fe})]$ et de la teneur en $\mathrm{Cl}$ de la biotite au cours de l'évolution des porphyroblastes. Un transfert différentiel de $\mathrm{Mg}$ et de Fe a eu lieu aux dépens des albitites en direction des schistes avoisinants, surtout au cours de $\mathrm{D}_{1}$, et la valeur de $\mathrm{Mg} \#$ de la biotite des roches métasomatiques a largement été fixée à cette époque. La teneur en $\mathrm{Cl}$ de la biotite de la matrice varie considérablement d'un des centres d'albitization à l'autre, d'inférieure au seuil de détection jusqu'à un maximum de 1.5\% (poids). Cette observation pourrait indiquer que l'enrichissement en $\mathrm{Cl}$ n'est pas liée à l'albitisation, mais il y a néanmoins une relation globale entre ces phénomènes dans l'espace. Dans un échantillon quelconque, la teneur en $\mathrm{Cl}$ de la biotite de la matrice dépasse en général celle de la biotite incluse dans l'andalousite tardive, et les inclusions dans l'andalousite précoce sont les plus dépourvues en $\mathrm{Cl}$. L'enrichissement de la biotite en $\mathrm{Cl}$ est fonction de $f(\mathrm{HCl}) / f\left(\mathrm{H}_{2} \mathrm{O}\right)$ plutôt que de salinité, et donc pourrait être liée au remplacement de la muscovite par l'albite, qui implique la libération de $\mathrm{H}^{+}$. Le rapport $f(\mathrm{HCl}) / f\left(\mathrm{H}_{2} \mathrm{O}\right)$ aurait été faible durant les périodes de flux élevé de fluides impliqués dans la production des albitites, mais aurait augmenté là où le flux était plus faible aux stades tardifs de l'albitisation, avec comme résultat un enrichissement maximum en $\mathrm{Cl}$ relativement tard dans l'évolution métasomatique.

(Traduit par la Rédaction)

Mots-clés: andalousite, métasomatose, albitisation, biotite, enrichissement en $\mathrm{Cl}$, région de Cloncurry, Australie.

e-mail address: michael.rubenach@jcu.edu.au 


\section{INTRODUCTION}

Studies of porphyroblast-matrix relationships have contributed significantly to our understanding of metamorphic processes and to the relative timing of thermal and structural events. A comparison of patterns of inclusion trails in porphyroblasts with matrix foliations indicates not only the timing of metamorphic events relative to deformation history (Zwart 1960, Vernon 1978), but also the sequential timing with respect to the development of a crenulation cleavage during a specific deformation event (Bell \& Rubenach 1983, Reinhardt \& Rubenach 1989). Metamorphic microstructures may also reveal information about reaction processes in metamorphic rocks. In a landmark study, Dugald Carmichael (1969) convincingly argued that reactions in schists commonly proceed via complex pathways, involving matrix minerals in a catalytic capacity (in addition to their role as reactants or products), with coupled ionic diffusion through intergranular fluids between sites of dissolution and growth. Prior to Carmichael's study, no adequate explanations existed for the development of textures around porphyroblasts in schists due to a prograde reaction.

In previous studies of schists from the Snake Creek Anticline, Rubenach \& Barker (1998) and Rubenach \& Lewthwaite (2002) documented the common occurrence of albitites (as veins, as a replacement of metapsammitic rocks, and along shear zones). They also used the presence or absence of albite inclusions in porphyroblasts of andalusite, staurolite, garnet and cordierite to argue that albitization has been the result of synmetamorphic metasomatism, as opposed to concentration of $\mathrm{Na}$ during diagenetic processes in the sedimentary protoliths. Thus inclusion trails in porphyroblasts were found to be instrumental in placing metasomatic events within a P$\mathrm{T}-\mathrm{t}$ (pressure - temperature - time) path. Rubenach \& Lewthwaite (2002) further proposed that biotite alteration of schists adjacent to albitites was related to albitization. Routine electron-microprobe analyses indicate that biotite grains in the metasomatic rocks are commonly enriched in chlorine, and that such enrichment defines complex patterns in space and time. In this paper, I describe the spatial distribution of chlorine enrichment in biotite, and compare the composition of matrix biotite with that of biotite included in various growth-zones within andalusite porphyroblasts. Combining biotite composition with microstructural development allowed investigation of the relative timing of albitization and $\mathrm{Cl}$ enrichment in biotite, and led to a test whether or not the two processes are genetically related. Although albitization may be linked to infiltration of saline fluids (Oliver et al. 1993, Williams et al. 1999), experimental and thermodynamic studies indicate that chlorine enrichment in biotite is a function of $\mathrm{HCl}$ activity rather than salinity (Munoz \& Swenson 1981, Zhu \& Sverjensky 1991). There is, therefore, no necessary link between $\mathrm{Cl}$ enrichment in biotite and albitization.

\section{Geology of the Snake Creek Anticline}

The Snake Creek area is situated about $20 \mathrm{~km}$ south of Cloncurry on the Roxmere cattle property, and is accessed along the western side by tracks. The region has low annual rainfall and sparse vegetation that includes spinifex grass. Numerous ephemeral streams and low hills provide localized good exposure.

The study area forms part of the Eastern Fold Belt of the Proterozoic Mount Isa Inlier (Figs.1, 2). Sedimentation occurred in intracontinental rift basins that have been grouped into three cover sequences (Blake \& Stewart 1992). Rocks in the Snake Creek area consist of the Corella beds (cover sequence 2, depositional age 1760-1725 Ma), which are in tectonic contact with the Soldiers Cap Group (cover sequence 3, depositional ages 1712-1654 Ma) (Page \& Sun 1998). The Corella beds are mainly scapolite-bearing calc-silicate rocks that have been extensively brecciated and hydrothermally altered. The Soldiers Cap Group consists of a lower unit of rhythmically bedded metapsammite and schist (Llewellyn Creek Formation), formed by metamorphism of turbidites, overlain by a unit of schist, metapsammite, quartzite and amphibolite (the Mount Norna Quartzite). A sill complex of gabbro, dolerite and tonalite intruded near the top of the Llewellyn Creek Formation prior to deformation, the mafic rocks being largely converted to amphibolite.

Deformation and metamorphism of the Snake Creek area occurred episodically during the Isan Orogeny, which extended from 1610 to $1500 \mathrm{Ma}$. Intrusion of mainly granitic magmas that led to the Williams and Naraku batholiths (1547-1500 Ma) overlapped with the latter half of the Isan Orogeny (Page \& Sun 1998). Lowpressure and high-temperature metamorphism is recorded by multiple events of porphyroblast growth. Metamorphic zones for the Snake Creek Anticline (Fig. 2) are composite, wherein andalusite, garnet, staurolite, kyanite and sillimanite exhibit multiple growth (Table 1). The sillimanite - K-feldspar zone is related to the relatively late $1520-1536$ Ma Saxby Granite, one of units of the Williams Batholith.

The structural evolution of the Snake Creek area used in this paper is after Rubenach \& Lewthwaite (2002), who recognized five major events. The first three were associated with penetrative strain $\left(D_{1}, D_{2}\right.$, $D_{3}$ ) whereas the effects of $D_{4}$ and $D_{5}$ were more localized. The first two events probably resulted from generally north-south compression. Event $\mathrm{D}_{1}$ produced folds with shallowly dipping axial planes and east-northeasterly-trending fold axes (Loosveld 1989), whereas $\mathrm{D}_{2}$ resulted in upright east-west folds (Rubenach \& Lewthwaite 2002). Folds and matrix foliations produced in the $\mathrm{D}_{1}$ and $\mathrm{D}_{2}$ events are only locally preserved, but 


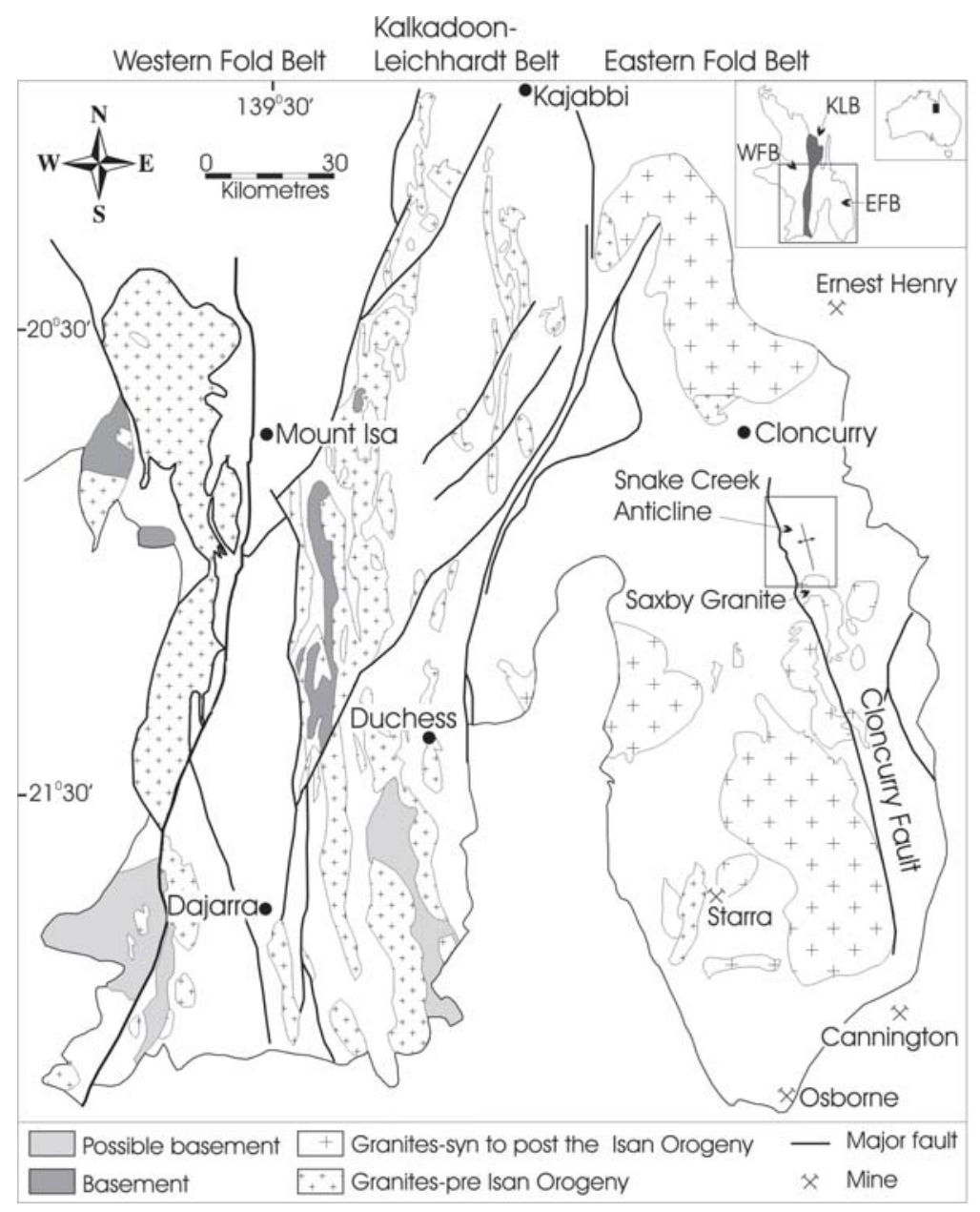

FIG. 1. Map of the Mount Isa Inlier, showing the location of the Snake Creek Anticline south of Cloncurry, in the Eastern Fold Belt.

$S_{1}$ and $S_{2}$ are well preserved as trails of inclusions in porphyroblasts (Rubenach \& Lewthwaite 2002). The $\mathrm{D}_{3}$ event resulted from east-west compression, which produced folds and the dominant steeply dipping northsouth foliation in the Eastern Fold Belt. The Snake Creek Anticline is interpreted as an $\mathrm{F}_{3}$ fold, the southern part of which is an antiformal syncline because of interference with a recumbent $\mathrm{F}_{1}$ fold. The $\mathrm{D}_{3}$ event (Rubenach \& Lewthwaite 2002, this paper) is referred to as $\mathrm{D}_{2}$ in other publications (e.g., Rubenach \& Barker 1998 , Oliver et al., in press). Event $\mathrm{D}_{4}$ resulted in crenulations and rare mesoscopic folds with shallowly dipping axial planes. The effects of $\mathrm{D}_{4}$ are mainly observed in the Mount Norna Quartzite, in the western part of the area, as are the steep north-northwesterly-trending crenulations produced in the $\mathrm{D}_{5}$ event. The peak of metamorphism, represented by the growth of sillimanite, occurred somewhere between late $\mathrm{D}_{3}$ and early $\mathrm{D}_{4}$ on the basis of microstructures, but andalusite growth can be related to each of the above five events (Rubenach \& Lewthwaite 2002). Note that the isograds sharply cut the stratigraphy in the west and northwest of the area (Fig. 2), and the apparent folding of isograds by the Snake Creek Anticline is possibly due to its reactivation during $\mathrm{D}_{5}$. On the basis of pseudosections and phase diagrams determined using THERMOCALC for assemblages in the systems KFMASH and NASH, conditions of metamorphism for the sillimanite isograd were found to be around $580 \mathrm{C}$ and $400 \mathrm{MPa}$ (M.J. Rubenach, unpubl. data). Earlier, some investigators (e.g., Rubenach \& Barker 1998, Rubenach \& Lewthwaite 2002) suggested that the peak of metamorphism in the 


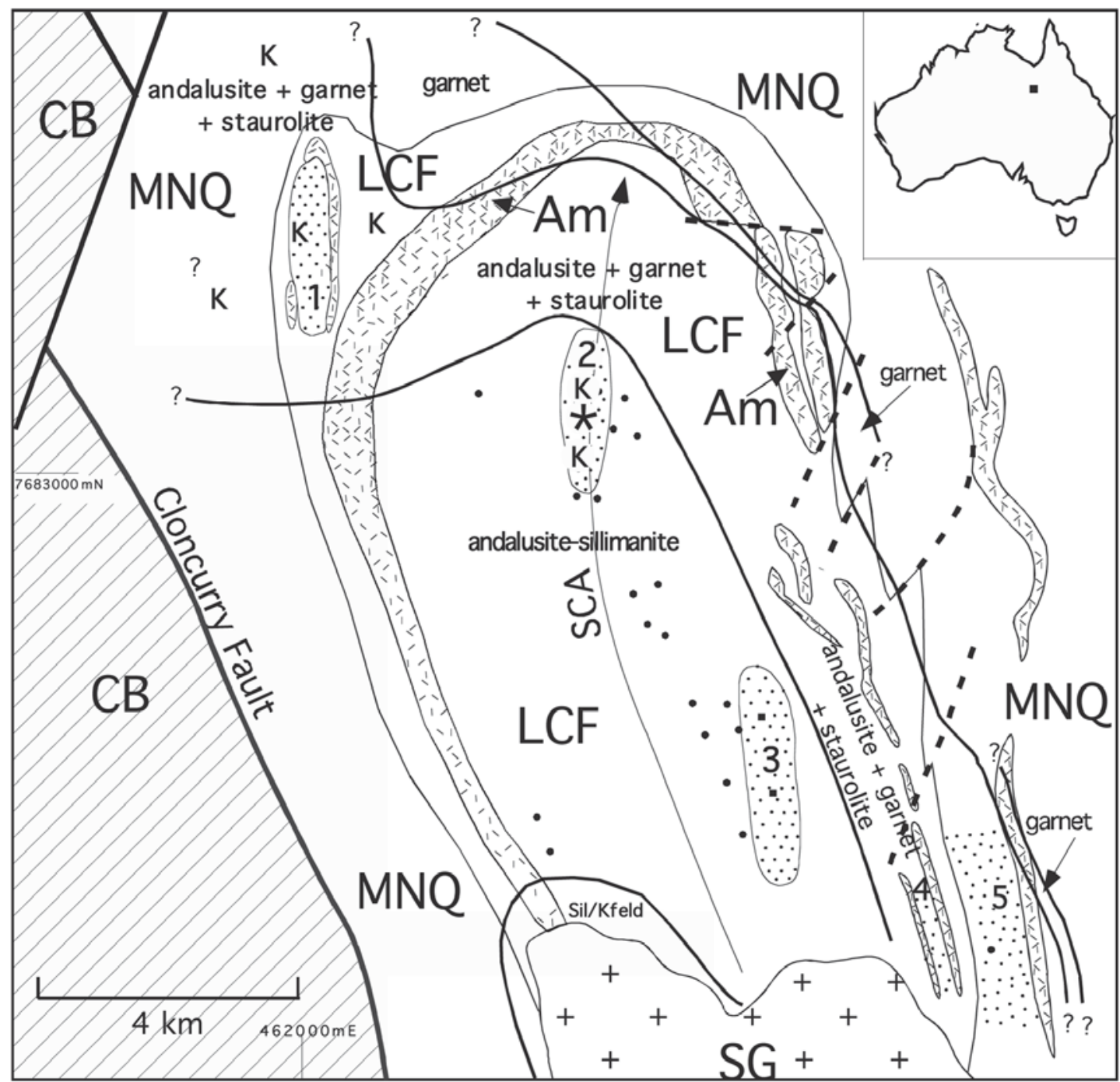

FIG. 2. Map of the Snake Creek area, modified from Rubenach \& Lewthwaite (2002). Geological units are as follows: CB: Corella beds, LCF: Llewellyn Creek Formation, MNQ: Mount Norna Quartzite, SG: Saxby Granite, and AM: amphibolite. Metamorphic zones and isograds are shown, along with kyanite localities (K), cordierite localities (filled circles), and the axial trace of the Snake Creek Anticline (SCA). Definite faults are shown as heavy lines, and possible faults as heavy dashed lines. Areas of intense albitization are designated 1-5, but albitite occur throughout the Lewellyn Creek Formation. Cordierite occurrences are closely associated with local albitite. Locality 430 in area 2 is shown as a star.

Eastern Fold Belt took place at $c a .1540$ Ma because of the occurrence of foliated granites with igneous ages of 1545-1547 Ma. However, recent U-Pb dates of monazite, zircon, and titanite indicate metamorphic ages of 1580-1600 Ma (Giles \& Nutman 2002, Gautier et al. 2001, Rubenach et al. 2001), consistent with an earlier U-Pb SHRIMP date of $1584 \mathrm{Ma}$ for a zircon rim in a gneiss (Page \& Sun 1998). I now believe that the folia- tions in the 1545-1547 Ma granites formed in localized shear-zones that postdated the peak of metamorphism.

Low-pressure metamorphism, in part recorded by episodic growth of andalusite, occurred throughout the Mount Isa Inlier. The intrusion of magmas made the most significant contribution to thermal perturbations in the middle crust during the Isan Orogeny (Foster \& Rubenach 2001). In the Snake Creek area, a north- 
south-striking swarm of basalt dykes intruded during $\mathrm{D}_{3}$, with numerous dykes parallel to $S_{3}$ and possessing $S_{3}$ foliations. Syn- $\mathrm{D}_{3}$ pegmatite sheets are fairly common in the sillimanite zone. In the south of the area, a composite body of Saxby Granite consists of monzogranite, granite and subordinate basaltic rocks. To the south of the area, other bodies of Saxby Granite have provided SHRIMP U-Pb (zircon) ages between $1536 \angle 12$ and $1520 \angle 8 \mathrm{Ma}$. Mark et al. (1999) suggested that $\mathrm{D}_{5}$ was ca.1527 Ma on the basis of SHRIMP dating of two granites, one foliated and the other unfoliated. The western half of Saxby Granite in the Snake Creek area shows abundant evidence of magma mingling and mixing of granitic and mafic rocks, and an aureole of sillimanite $\mathrm{K}$-feldspar gneisses up to $1 \mathrm{~km}$ wide (Fig. 2). The metamorphism of these gneisses was previously interpreted as syn- $\mathrm{D}_{3}$ (Rubenach \& Lewthwaite 2002). In contrast, the aureole surrounding the eastern half of the Saxby Granite, where there are no mingled mafic rocks, is typically only meters wide, with the development of intrusion-related andalusite and sillimanite in muscovite schists. The higher-temperature aureole is likely to be related to the higher proportion of mafic rocks in the western half of the Saxby Granite body.

The Cloncurry Fault is interpreted as dipping about 35 to the east on the basis of a seismic traverse situated just north of the study area (Goleby et al. 1996). Thus the Soldiers Cap Group structurally overlies the older Corella beds, implying that the main movement on the fault was extensional. However, reactivation of the fault as a post- $\mathrm{D}_{3}$ thrust is highly likely, as sillimanite-zone Soldiers Cap rocks have been juxtaposed against greenschist-facies rocks of the Corella beds. Abundant small bodies of granite and gabbro have been emplaced along the Cloncurry Fault, and are associated with extensive development of calc-silicate breccias, with al-

TABLE 1. CHART SUMMARIZING THE TIMING OF ALBITIZATION, CHLORINE ENRICHMENT, AND PORPHYROBLAST GROWTH UP TO THE END OF $\mathrm{D}_{5}$, SNAKE CREEK ANTICLINE, MOUNT ISA INLIER, AUSTRALIA

\begin{tabular}{|c|c|c|c|c|c|}
\hline & $D_{1}$ & $\mathrm{D}_{2}$ & $\mathrm{D}_{3}$ & $\mathrm{D}_{4}$ & $\mathrm{D}_{5}$ \\
\hline cordierite & - & & & & \\
\hline garnet & & & & & - \\
\hline staurolite & & & 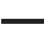 & - & . \\
\hline andalusite & $?$ & & & & \\
\hline kyanite & & & & & \\
\hline sillimanite & & & & & \\
\hline albite & & $?$ & 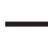 & $?$ & \\
\hline $\mathrm{Cl}$ enrichment & 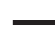 & $?$ & & $?$ & \\
\hline
\end{tabular}

The heavier lines denote periods of more intense albitization (episode $\mathrm{D}_{1}$ ) and $\mathrm{Cl}$ enrichment (episode $D_{3}$ ). teration assemblages including combinations of calcite, albite, K-feldspar, pyroxenes (diopside-hedenbergite, aegirine-augite), amphiboles (actinolite, ferrohastingsite, magnesioriebeckite), magnetite, and hematite.

The Eastern Fold Belt is noted for the widespread occurrence of $\mathrm{Fe}$-oxide - $\mathrm{Cu}-\mathrm{Au}$ and $\mathrm{Pb}-\mathrm{Zn}-\mathrm{Ag}$ mineralization (Williams 1998). Most of the deposits have at least some associated albitites, and the Osborne $\mathrm{Cu}-$ $\mathrm{Au}$ deposit is hosted in a thick package of albitized gneisses (Adshead et al. 1998). Albitites, pegmatites and mineralization at the Osborne mine have been dated at ca. $1595 \mathrm{Ma}$ (Gautier et al. 2001, Rubenach et al. 2001). However, $\mathrm{U}-\mathrm{Pb}$ dating of titanite from calc-silicatehosted albitites elsewhere in the Eastern Fold Belt have yielded ages of 1521-1555 Ma, a range overlapping with the emplacement of the Williams-Naraku batholiths and the formation of the Eloise and Ernest Henry $\mathrm{Cu}-\mathrm{Au}$ deposits (Oliver et al., in press).

In conclusion, intrusions of granitic magma, lowpressure metamorphism, extensive metasomatism (notably albitization) and $\mathrm{Cu}-\mathrm{Au}$ mineralization occurred periodically throughout the 1500-1610 Ma Isan Orogeny.

\section{Albitites and Biotite-Rich Schists}

Details of the mineral assemblages and development of albitites and related biotite-rich schists are given in Rubenach \& Barker (1998) and Rubenach \& Lewthwaite (2002). Albitites are abundant throughout the Llewellyn Creek Formation, less so in the Mount Norna Quartzite, but are concentrated in five areas (Fig. 2). Albitites occur in three settings: (1) as replacement of pelitic schists and metapsammitic rocks along $\mathrm{D}_{1}$ shear zones (up to several meters wide), (2) as selective replacements of muscovite-bearing metapsammite beds near shear zones, and (3) as infill veins of thickness less than $1 \mathrm{~cm}$. They are comprised of fine-grained granular albite, accessory rutile or ilmenite, with or without quartz and biotite, and locally contain garnet, staurolite, cordierite, andalusite, kyanite, sillimanite and gedrite. Albite compositions are in the range $\mathrm{An}_{0-7}$, with compositions of $\mathrm{An}_{2-3}$ being most common. Staurolite and garnet are more common in areas 1, 4 and 5, whereas cordierite is quite abundant in areas 2 and 3 , and is also strongly associated with minor occurrences of albitite throughout the core of the Snake Creek Anticline (Fig. 2). Garnet and cordierite are mutually exclusive. Albitites that have replaced pelitic rocks commonly contain more than $90 \%$ albite with little to no quartz, whereas albitized metapsammites contain $20-80 \%$ quartz. Biotite-rich schists typically occur adjacent to shear zones, and range in width from less than 1 meter to tens of meters (Figs. 3, 4). They are generally quartzbearing, free of muscovite, and consist of similar assemblages to the albitites, but with albite generally less than $20 \%$ and biotite over $40 \%$. Contacts between replacement albitites and biotite-rich schists are generally quite 


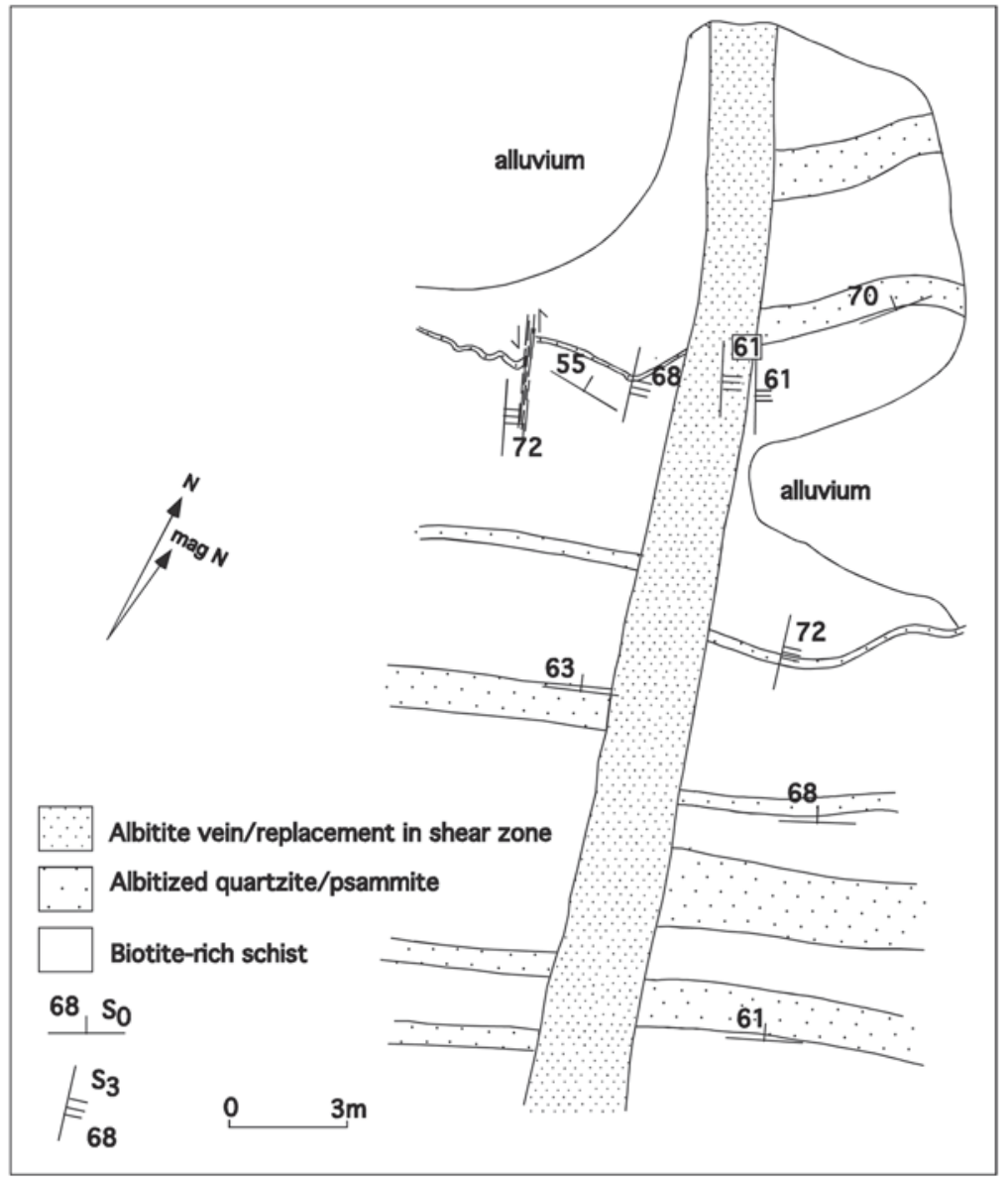

FIG. 3. Map of the location 430, area 2, modified from Rubenach \& Lewthwaite (2002). The central albitite occupies a shear zone in the hinge of a $\mathrm{F}_{3}$ fold, and consists of finegrained albite with minor biotite and localized cordierite replaced by albite and biotite. The biotite-rich schists are metasomatized and pelitic to semipelitic in composition, and consist of biotite, quartz, replaced cordierite, andalusite, albite and localized muscovite. Thin lenticular veins of albite occur in schists and are parallel to the main vein.

sharp, whereas contacts between the biotite-rich schists and the muscovite-bearing schists and metapsammitic rocks that they replaced are either sharp or gradational.

Extensive post- $\mathrm{D}_{3}$ albitization also occurs in association with breccias in the Corella beds, and in the Mount Norna Quartzite adjacent to the Cloncurry Fault (de Jong \& Williams 1995, Oliver et al., in press), but is not considered in this study.

\section{Timing of albitization}

Rubenach \& Lewthwaite (2002) proposed that the albitization that produced the majority of the albitites and biotite-rich schists was syn- $\mathrm{D}_{3}$, partly on the basis of occurrences of steeply dipping albitite in shear zones of north-south orientation, such as location 430 shown in Figure 3. However, a recent discovery in area 3 of albite veins and alteration oriented parallel to the axial planes of $F_{1}$ recumbent folds strongly suggests the presence of some syn- $\mathrm{D}_{1}$ albitization. This is supported by thin-section studies indicating that the coarser infill of veins has been recrystallized to finer-grained albite in zones parallel to $S_{1}$ (Fig. 5), and biotite grains in the adjacent biotite-rich schist are clearly oriented in both the $S_{1}$ and $S_{3}$ directions.

Whereas away from zones of albitization, "unmetasomatized" andalusite schists commonly contain garnet, cordierite is typically associated with albitization. This 


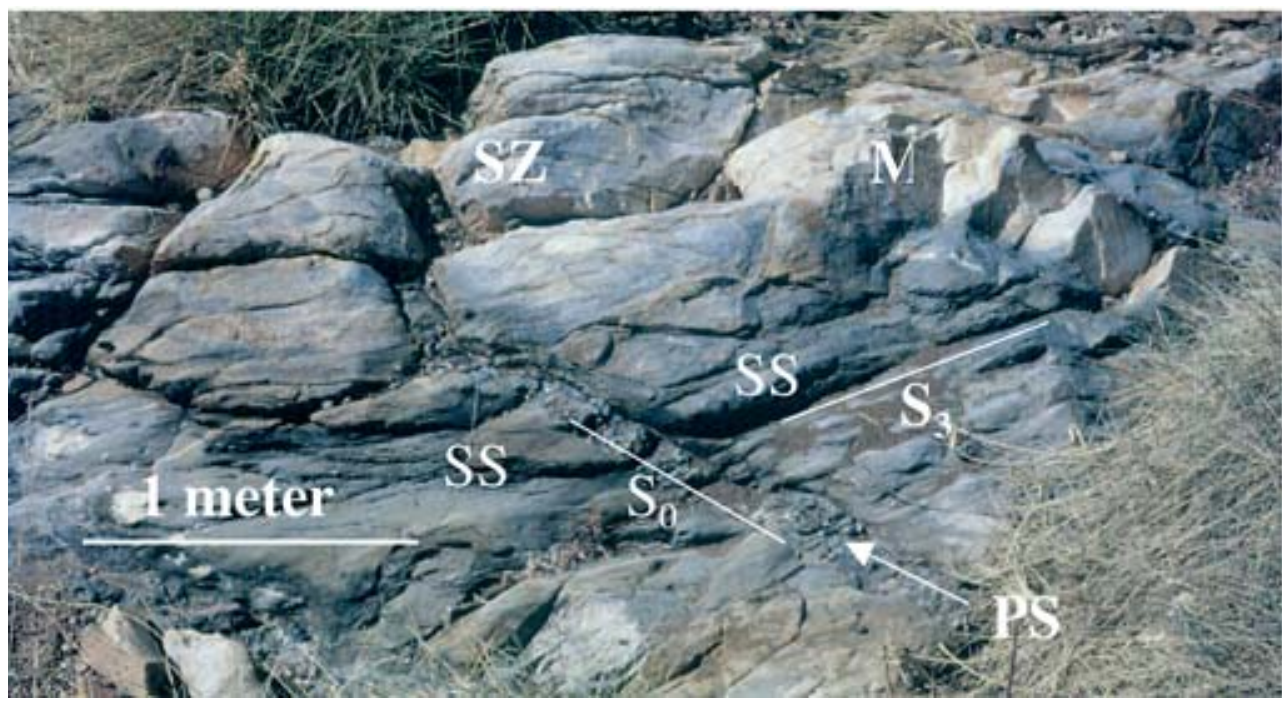

FIG. 4. Field photograph showing a body of albitite in a shear zone (SZ), a layer of albitized metapsammite (M), layers of pelitic schist (PS) and layers of semischist (SS). The pelitic and semischist layers consist of biotite, quartz and albite, with abundant andalusite and replaced cordierite in the pelitic layer. Bedding is transected by the foliation $\left(\mathrm{S}_{3}\right)$ at a high angle. The location is in area 2, a few hundred meters north of location 430.

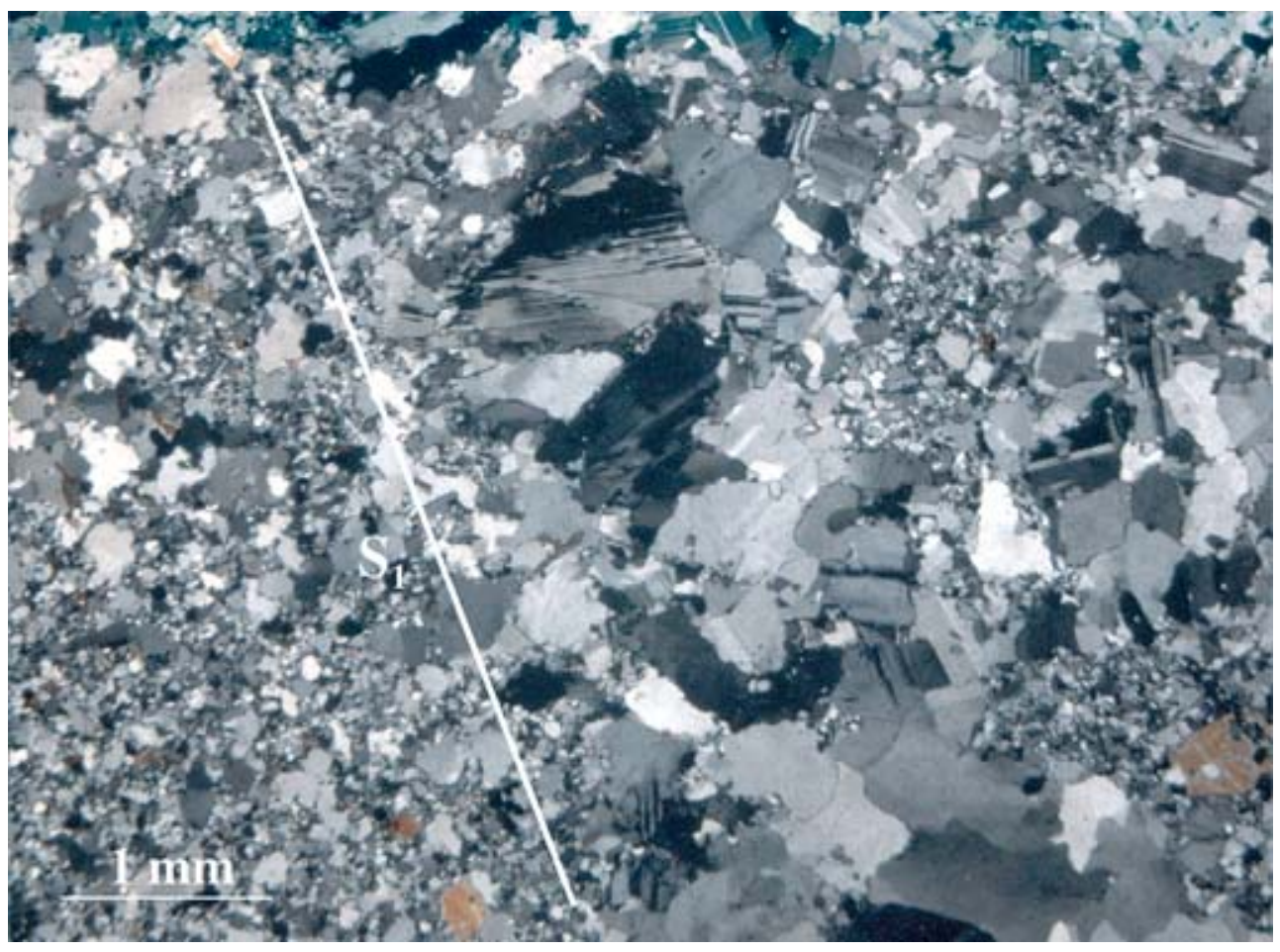

FIG. 5. Photomicrograph of a deformed vein of albitite. Coarser grains of albite are relics from a vein, with the rest of the vein having been recrystallized to finer-grained aggregates during $D_{1}$. The orientation of $S_{1}$ is indicated. Elsewhere in this thin section, albite-biotite schist shows biotite in both the $\mathrm{S}_{1}$ and $\mathrm{S}_{3}$ orientations. Crossed nicols. 
can be explained by differential movement of $\mathrm{Mg}, \mathrm{Fe}$ and $\mathrm{Mn}$ during metasomatism, which led to an increase in $\mathrm{Mg \#}$ [i.e., $\mathrm{Mg} /(\mathrm{Mg}+\mathrm{Fe})]$ in schists, favoring cordierite growth over garnet (M.J. Rubenach, unpubl. data). Most cordierite has reacted to form andalusite according to the reaction:

$$
\mathrm{Crd}+\mathrm{Ms}+\mathrm{Qtz}=\mathrm{And}+\mathrm{Bt}
$$

Relict porphyroblasts of cordierite are only preserved in situations where they were protected from reaction with muscovite, such as in a few cores of andalusite, and in some muscovite-free albite-rich rocks, where they are rimmed by biotite and andalusite or, less commonly, staurolite, kyanite and sillimanite. Most cordierite has been replaced by various combinations biotite, albite, quartz, andalusite and tourmaline. Catalytic processes and coupled ionic diffusion between sites of dissolution and growth were likely to be involved in the replacement of cordierite, according to the model first presented by Carmichael (1969) for kyanite-sillimanite reactions. Cordierite has been generally replaced by biotite and quartz, with or without albite and tourmaline, whereas andalusite replaced matrix muscovite, quartz, biotite and albite. Direct replacement of cordierite by andalusite occurred only where the relatively larger porphyroblasts of andalusite enveloped cordierite already partly replaced by biotite. Potassium, $\mathrm{Mg}, \mathrm{Fe}, \mathrm{Si}$ and possibly Al were exchanged between sites of cordierite replacement and andalusite growth.

Evidence was presented in Rubenach \& Lewthwaite (2002, their Fig. 6a) that at least some cordierite overgrew $\mathrm{S}_{2}$, either late in $\mathrm{D}_{2}$ or early in $\mathrm{D}_{3}$. However, additional oriented samples used in this study have revealed the presence of some cordierite porphyroblasts with inclusions that are either not obviously oriented or define a weak $S_{1}$ foliation. Inclusions of albite occur in these cordierite porphyroblasts, providing additional support for the syn- $\mathrm{D}_{1}$ occurrence of albitization. Andalusite porphyroblasts in samples from areas 2 and 3 commonly exhibit several stages of growth. Inclusions of quartz and biotite in stage- 1 and stage- 2 andalusite are typically relatively fine-grained, whereas inclusions in stage- 3 andalusite are coarser, generally of similar grainsize and orientation as grains in the adjacent matrix. Stage-1 andalusite, by far the most abundant, either lacks trails of inclusions or shows trails that define a weak shallowly dipping $S_{1}$ foliation (Fig. 6). In the latter case, andalusite is interpreted as growing in the late syn- $\mathrm{D}_{1}$ to early syn- $\mathrm{D}_{2}$ period. Replaced porphyroblasts of cordierite are commonly included in stage-1 andalusite, indicating that such cordierite grew prior to, or possibly overlapping with, stage- 1 andalusite. Stage 2 is only rarely developed, and consists of andalusite that has overgrown a relatively fine-grained foliation $\left(\mathrm{S}_{1}\right)$ that has in places has been folded by open microfolds, possibly $\mathrm{F}_{2}$ (Figs. 7, 8). Stage- 3 andalusite is fairly common, but occurs as a quite narrow overgrowth on earlier andalusite, in some samples truncating foliations preserved in stage 1 or 2 (Fig. 6). In some rocks, stage-3 andalusite also occurs as elongate grains extending parallel to the axial traces of $F_{3}$ microfolds. Stage- 3 andalusite probably grew at some point in the late syn- $\mathrm{D}_{3}$ to early syn- $\mathrm{D}_{4}$ period.

The above structural and microstructural observations, mainly from areas 2 and 3 , indicate that albitization commenced during $\mathrm{D}_{1}$. However, in other samples, albite is abundant in the matrix, but lacking in porphyroblasts with $S_{2}$ inclusion trails, suggesting that some albitization also occurred during $\mathrm{D}_{3}$ (Rubenach \& Lewthwaite 2002, Fig. 6c). In addition, Rubenach \& Barker (1998) documented planar veins of albite cutting $\mathrm{S}_{3}$, suggestive of late syn- to post- $\mathrm{D}_{3}$ emplacement. In sample 430.4, all three stages of andalusite contain albite inclusions, but they are subordinate to quartz (Fig. 8). However, the immediately adjacent matrix locally contains abundant albite that transects the folded $\mathrm{S}_{1}$ foliation and has replaced quartz, suggesting that most albite in this sample formed late syn- to post- $\mathrm{D}_{3}$. The albite thus seems to have formed over a protracted period from syn- $\mathrm{D}_{1}$ to post- $\mathrm{D}_{3}$, although albitites that formed syn- $\mathrm{D}_{1}$ are probably the most abundant. Given the structural controls, albitization was probably episodic rather than continuous. Table 1 provides a summary of the timing of metamorphism and metasomatism, and include data on the timing of $\mathrm{Cl}$ enrichment in biotite, as discussed below.

Another problem in timing requiring consideration is the north-south orientation of albitite-replaced shear zones in areas $1-3$, particularly those in the hinges of $F_{3}$ folds. These shear zones were interpreted as forming in $D_{3}$ rather than the $D_{1}$ or $D_{2}$ events, both of which produced east-west structures (Rubenach \& Lewthwaite 2002). However, andalusite containing albite along with straight $S_{1}$ trails of inclusions occurs in schists immediately adjacent to the shear zones, suggesting that albitization had commenced prior to $\mathrm{D}_{3}$. The occurrence adjacent to north-south shear zones of relict $S_{1}$ and $S_{2}$ at some localities precludes the possibility that the shear zones represent rotated $\mathrm{D}_{1}$ or $\mathrm{D}_{2}$ structures. The shear zones possibly represent north-south accommodation structures separating areas of different $\mathrm{D}_{1}$-related strain, as $F_{1}$ mesoscopic folds are more common in the eastern half of the Snake Creek Anticline. If so, the shear zones were certainly reactivated during $\mathrm{D}_{3}$.

\section{Biotite Compositions}

In this section, I consider the chlorine content and $\mathrm{Mg} /(\mathrm{Mg}+\mathrm{Fe})$ proportion in biotite from Snake Creek, and contrast (nonmetasomatic) muscovite schists with albitites and associated biotite-rich metasomatic schists (Table 2). Routine electron-microprobe analyses of biotite revealed significantly high $\mathrm{Cl}$ contents in many samples, in particular those from biotite-rich schists. The variation in biotite compositions within different 
stages of growth of andalusite was documented, and possible relationships between albitization and $\mathrm{Cl}$ enrichment were examined. Fluorine was not detected. Biotite grains commonly occur as inclusions in andalusite porphyroblasts that may have protected them from subsequent reactions in the matrix and from interaction with any later-stage infiltrating fluids. Thus each event of andalusite growth potentially preserves the composition of biotite that existed at that particular stage.

It has been demonstrated that $\mathrm{Cl}$ in biotite is a function of $\mathrm{HCl}$ in fluids, not simply $\mathrm{NaCl}$ or other chlorides in solution (e.g., Munoz \& Swenson 1981). A revised expression for Cl-OH in biotite (Munoz 1992), based on the thermodynamic data of Zhu \& Sverjensky (1991) and of Munoz (1992), is as follows:

$$
\begin{aligned}
& \log f\left(\mathrm{H}_{2} \mathrm{O}\right) / f(\mathrm{HCl})=1000 / \mathrm{T}\left(1.15-0.55 X_{\mathrm{Mg}}\right) \\
& +0.68-\log \left(X_{\mathrm{Cl}} / X_{\mathrm{OH}}\right),
\end{aligned}
$$

where $X_{\mathrm{Mg}}$ is $\mathrm{Mg} /$ (sum of octahedrally coordinated cations), and $X_{\mathrm{Cl}}$ is the mole fraction of $\mathrm{Cl}$ in the hydroxyl site. As well as the $f\left(\mathrm{H}_{2} \mathrm{O}\right) / f(\mathrm{HCl})$ ratio, the maximum amount of $\mathrm{Cl}$ that can be incorporated in biotite depends on $X_{\mathrm{Mg}}(\mathrm{Mg \#})$, owing to $\mathrm{Mg}-\mathrm{Cl}$ avoidance (Munoz 1984, Oliver et al. 1992).

Figure 9 shows Mg\# versus chlorine contents of matrix biotite and biotite inclusions in andalusite for unmetasomatized muscovite schists, metasomatic biotite-rich schists, and albitites. In Tables 3 and 4, I summarize biotite compositions in the various lithologies and areas of albitization, respectively. Compositions range from annite to $\mathrm{Fe}$-rich phlogopite, with incorporation of the more aluminous siderophyllite end-member being less than $30 \%$. The "chlorine saturation line" indicates the maximum measured chlorine content of biotite at Snake Creek; given the negative slope of the

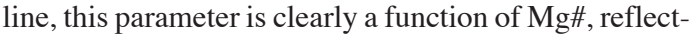
ing $\mathrm{Mg}-\mathrm{Cl}$ avoidance. However, matrix biotite compositions that plot along the "maximum $\mathrm{Cl}$ line" gave values of $\log \left(f\left(\mathrm{H}_{2} \mathrm{O}\right) / f(\mathrm{HCl})\right.$ in the range 3.0 to 4.0 [calculated at $580 \mathrm{C}$, according to Munoz (1992)]. This finding suggests an order-of-magnitude difference in $f\left(\mathrm{H}_{2} \mathrm{O}\right) / f(\mathrm{HCl})$ for fluids with relatively high $\mathrm{HCl}$ contents. Important observations and conclusions that can be drawn from biotite compositions (Figs. 9-10 and Tables 3 and 4) are summarized below:

1. Although there is overlap, the Mg\# values of biotite in many biotite-rich schists, especially in area 2 , are higher than those in unmetasomatized muscovite schists, the exceptions being some biotite-rich schists containing garnet or staurolite (or both). The differences in $\mathrm{Mg \#}$ are interpreted as being the result of differential movement of $\mathrm{Mg}$ and $\mathrm{Fe}$ during albitization and formation of the biotite-rich schists (see Discussion).

2. The $\mathrm{Cl}$ content of biotite in any particular sample of biotite-rich schist generally increases in the order early andalusite (mainly pre- $\mathrm{D}_{3}$ ), late andalusite (late syn- to post- $\mathrm{D}_{3}$ ) to matrix. In a few samples, however, biotite in inclusions in late andalusite has a higher $\mathrm{Cl}$ than that in the matrix. The corresponding values of $\mathrm{Mg}$ \# do not show a significant change, suggesting that $\mathrm{Mg}$ \# was essentially set early in the metasomatic history.

3. The $\mathrm{Cl}$ contents of biotite in the matrix and present as inclusions in late andalusite in biotite-rich schists vary, with each area showing a distinct range (Table 4). In area $1, \mathrm{Cl}$ contents are below detection in all samples. In area 2, they all lie close to the "chlorine saturation line". In areas 3-5, they are below the saturation line, and in some samples are below the detection limits.

4. In all areas, the $\mathrm{Cl}$ content of biotite in albitites is, with a few exceptions, below the saturation line, and some samples, including a few from area 2, are below detection limits.

Figure 10 shows $\mathrm{Mg \#}$ and wt $\% \mathrm{Cl}$ contents of biotite in the matrix of albitites and biotite-rich schists from location 430 (Fig. 3), plotted against distance from the main vein. Biotite grains in albitites have Mg\# value similar to those in immediately adjacent biotite-rich schists. There is a general decrease in $\mathrm{Mg \#}$ away from the main vein, except for high values in two samples collected over four meters away from the main vein. Most biotite-rich schists have a higher $\mathrm{Mg \#}$ than unmetasomatized muscovite schists, reflecting the differential movement of $\mathrm{Fe}$ and $\mathrm{Mg}$ during alteration (see Discussion).

Figure 11 shows $\mathrm{Mg \#}$ and $\mathrm{Cl}$ values for a single sample (430.4) of schist that has large porphyroblasts of andalusite and that shows a strong $\mathrm{S}_{1}$ foliation overprinted by $\mathrm{F}_{3}$ folds and an $\mathrm{S}_{3}$ crenulation cleavage (Figs. 7, 8). Particular layers were selectively metasomatized to albitite or biotite-albite schist, with some layers preserved as unaltered muscovite - quartz - biotite schist. Most of the andalusite in the sample belongs to stage 1, and has overgrown a weak shallowly dipping $S_{1}$ foliation. Stage 2 has overgrown a microfold, possibly $\mathrm{F}_{2}$, and stage 3 is a narrow rim that preserves a strong $S_{1}$ foliation and an $F_{3}$ microfold (Fig. 8). The fact that $S_{1}$ is weak in stage 1 but very strong in the matrix and in stage-3 andalusite implies that $S_{1}$ was reactivated and intensified prior to the development of the $\mathrm{F}_{3}$ microfold (Bell 1986). Significant variations were found in the composition of biotite in this sample. No obvious differences were found in matrix biotite in the muscoviterich and biotite-rich layers in the schist. The matrix values show a trend close to the maximum $\mathrm{Cl}$ line, the lowest values of $\mathrm{Cl}$ occurring immediately adjacent to andalusite. Biotite inclusions in stage- 1 andalusite show a trend that is at a high angle to the maximum $\mathrm{Cl}$ line, with very little overlap with matrix biotite. Stage-3 biotite inclusions are similar in composition to the highest- $\mathrm{Cl}$ and lowest-Mg\# matrix biotite, whereas stage-2 biotite extends from the low- $\mathrm{Cl}$ and low- $\mathrm{Mg} \#$ value of stage- 3 biotite. Note that sample 430.4 covers the entire 


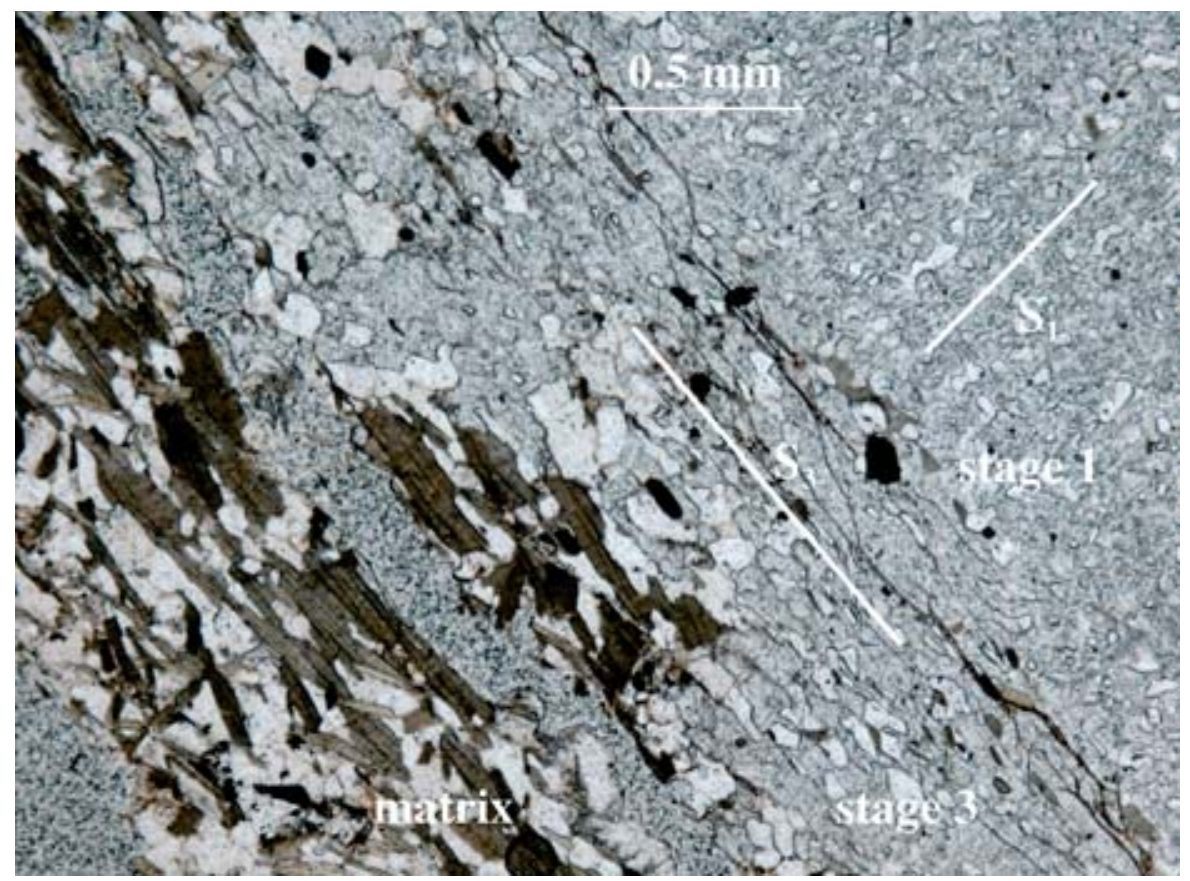

FIG. 6. Photomicrograph of part of a large porphyroblast of andalusite, most of which belongs to stage 1, with quartz and biotite inclusions that are weakly aligned in $\mathrm{S}_{1}$. Stage-1 andalusite probably grew sometime in the period late syn- $\mathrm{D}_{1}$ to syn- $\mathrm{D}_{2}$. A narrow rim of stage- 3 andalusite shows a strong $\mathrm{S}_{3}$ foliation defined by elongate grains of quartz and biotite, and probably grew in the period late syn- $\mathrm{D}_{3}$ to syn- $\mathrm{D}_{4}$. The matrix is biotite-rich schist composed of biotite, quartz and albite. Albite does not commonly form inclusions in the andalusite, but is abundant in replaced cordierite. Oriented sample 115 of Sayab Mohammad, location 430. Plane-polarized light.

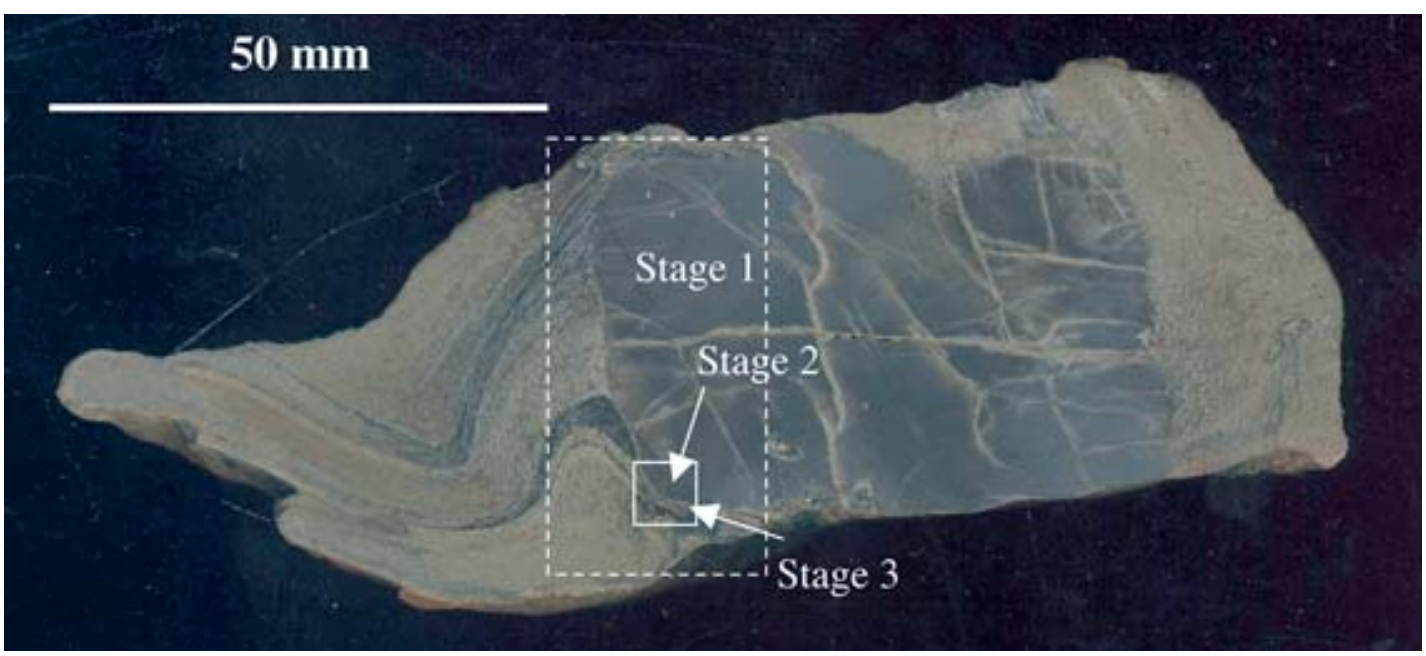

FIG. 7. Andalusite porphyroblast in schist, sample 430.4. Relict bedding $\left(\mathrm{S}_{0}\right)$ has been folded during $\mathrm{D}_{3}$ and is cut by an $\mathrm{S}_{3}$ crenulation cleavage. $S_{1}$ transects $S_{0}$ at a shallow angle. Some layers have been preferentially replaced by biotite and albite, but others remain as muscovite - quartz - biotite schist. Stages 1,2 and 3 of andalusite growth are indicated. Note the prominent dark biotite-rich layer showing an $\mathrm{F}_{3}$ fold. A weak $\mathrm{S}_{1}$ is preserved as trails of inclusions in stage-1 andalusite (compared with the strong $\mathrm{S}_{1}$ in the matrix). The dashed area is the location of a polished thin section used for analysis of biotite from the matrix and from each stage of andalusite. The results are plotted on Figure 11. The small box shows the location of Figure 8 


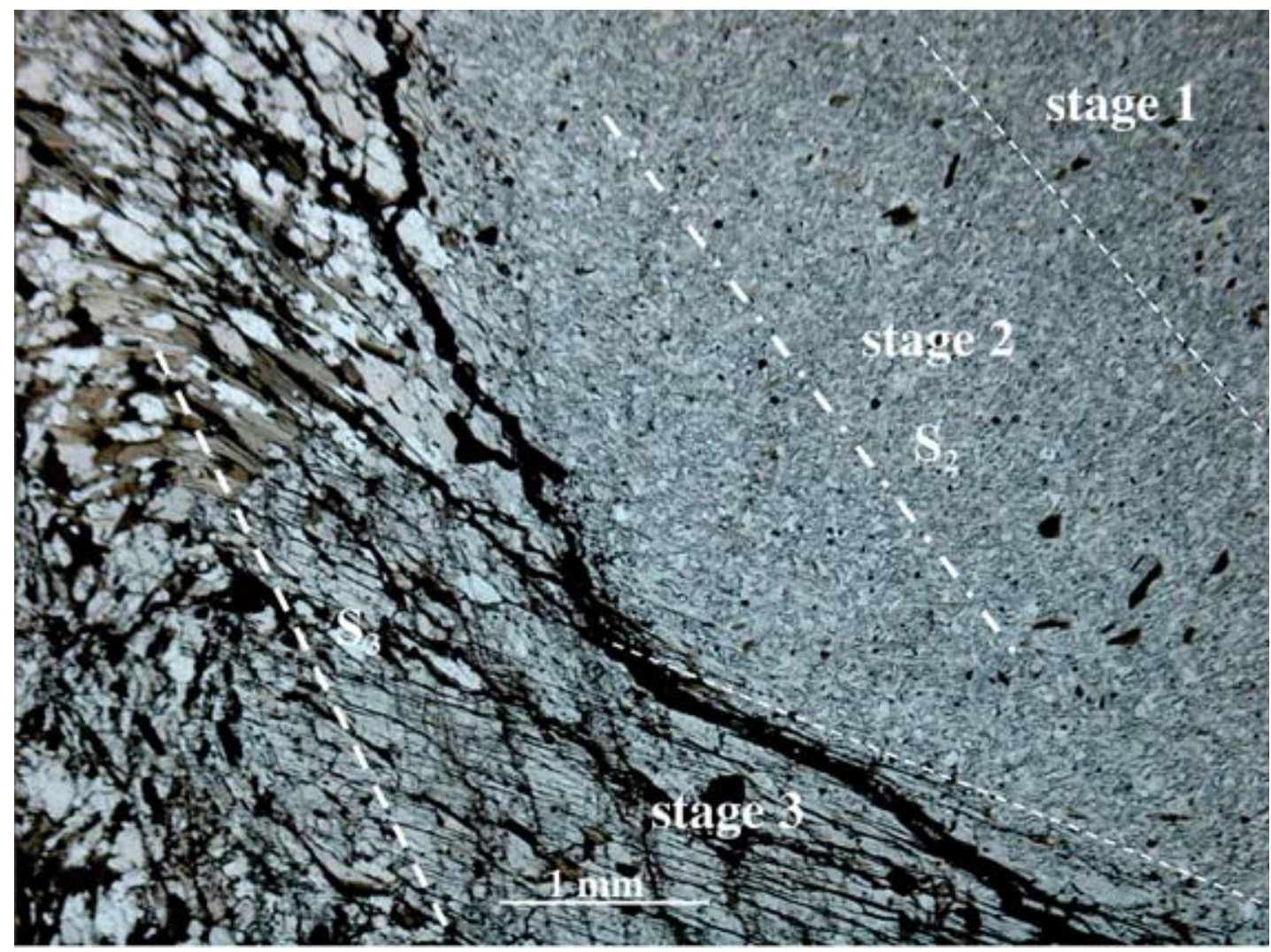

FIG. 8. Photomicrograph of specimen 430.4, showing three stages of andalusite, each of which contains inclusions of quartz, biotite and rare albite. Stage- 3 andalusite and the adjacent matrix preserve an $\mathrm{F}_{3}$ microfold, the axial trace of which is indicated. Inclusions in andalusite of stages 1 and 2 are relatively fine-grained and poor in biotite, contrasting with stage-3 inclusions and the matrix. The microfold preserved in stage-2 andalusite is possibly $\mathrm{F}_{2}$, and the axial trace is labeled. Grain coarsening and intensification of the $S_{1}$ foliation occurred between the growth of stages 2 and 3 , suggesting reactivation of $S_{1}$ prior to the development of the $\mathrm{F}_{3}$ microfold (see text). Plane-polarized light.

$\mathrm{Cl}$ range of all samples analyzed, whereas the range of $\mathrm{Mg \#} \mathrm{(0.35-0.45)}$ is restricted to the low values in Figure 9.

\section{DisCUSSION}

Rubenach \& Lewthwaite (2002) had earlier suggested that the widespread albitization in the Snake Creek Anticline commenced early in $\mathrm{D}_{3}$, mainly on the basis of shear zones of north-south orientation developed in albitite and the observation that in some albitites, porphyroblasts with $\mathrm{S}_{2}$ trails lack albite inclusions. Other porphyroblasts contain albite inclusions with or without $S_{1}$ or $S_{2}$ trails, but the occurrence of $S_{1}$ or $S_{2}$ trails does not preclude porphyroblast growth in a subsequent event, i.e., $\mathrm{D}_{3}$ in the Snake Creek Anticline (e.g., Bell \& Hayward 1991). New observations presented in this study, especially the occurrence of albitite showing $\mathrm{S}_{1}$ and occurring subparallel to the axial planes of $\mathrm{F}_{1}$ folds, indicate that albitization commenced during $\mathrm{D}_{1}$. Combined with the evidence for syn- $\mathrm{D}_{3}$ albitization (Rubenach \& Lewthwaite 2002) and the occurrence of post- $\mathrm{S}_{3}$ albitite veins (Rubenach \& Barker 1998), it is now clear that albitization extended from $\mathrm{D}_{1}$ to post- $\mathrm{D}_{3}$, with syn- $\mathrm{D}_{1}$ albitites probably being the most abundant.

Figure 12 shows a model intended to explain the relationship between albitites and adjacent metasomatic biotite-rich schists. Both $\mathrm{Fe}$ and $\mathrm{Mg}$ were removed from shear zones during the more extreme albitization, and deposited, along with variable amounts of $\mathrm{Na}$, to make biotite and albite in the adjacent rocks. Potassium was removed from both albitites and biotite-rich schists (Oliver et al., in press, M.J. Rubenach, unpubl. data). The values of $\mathrm{Mg} \#$ in biotite in albitites and biotite-rich 
schists are mainly higher than those in unmetasomatized muscovite schists, suggesting differential migration of $\mathrm{Mg}$ and Fe during alteration (Table 3, Figs. 9-10). It is also possible that some $\mathrm{Fe}$, along with $\mathrm{K}$, was removed from the system. The fact the $\mathrm{Mg \#}$ values for biotite occurring as inclusions in andalusite do not differ from that in the corresponding matrix by more than 0.1 suggests that most of the $\mathrm{Fe}$ and $\mathrm{Mg}$ movement occurred early in the history, probably during $\mathrm{D}_{1}$. However, a detailed study of sample 430.4 suggests that minor differential movement of $\mathrm{Mg}$ and $\mathrm{Fe}$ continued during and after $\mathrm{D}_{3}$ (Fig. 11).

In contrast to albitization and $\mathrm{Mg}-\mathrm{Fe}$ mass transport, maximum $\mathrm{Cl}$ enrichment in biotite occurred late in the alteration history, probably during $\mathrm{D}_{3}$. Such a decoupling of peak albitization and $\mathrm{Cl}$ enrichment could be interpreted in terms of two unrelated metasomatic events. The large variation in degree of $\mathrm{Cl}$ enrichment shown by biotite in the different areas of albitization, ranging from below detection in all samples in area 1 to near-saturation for matrix biotite in most biotite-rich schists in area 2, appears to support the notion of unrelated metasomatic events. Chlorine enrichment in biotite depends on the $\mathrm{HCl}$ content of fluid, such that infiltration of NaCl-rich fluids could produce albitization but

\begin{tabular}{|c|c|c|c|c|c|c|c|c|c|}
\hline mple & 404 & $\begin{array}{c}430 . \\
26\end{array}$ & $\begin{array}{c}430 \\
25\end{array}$ & $\begin{array}{l}430 . \\
4 / \mathrm{m}\end{array}$ & $\begin{array}{c}430 \\
4 / 3\end{array}$ & $\begin{array}{l}430 \\
4 / 2\end{array}$ & $\begin{array}{c}430 \\
4 / 1\end{array}$ & $\begin{array}{l}725 \\
3 / \mathrm{m}\end{array}$ & $\begin{array}{c}725 \\
3 / \mathrm{a}\end{array}$ \\
\hline \multicolumn{2}{|c|}{$\mathrm{SiO}, w t \% 34.82$} & 37.05 & 37.99 & 33.83 & 33.43 & 33.82 & 34.49 & 34.32 & 35.40 \\
\hline & 1.74 & 2.05 & 1.58 & 2.01 & 2.14 & 1.95 & 2.11 & 1.67 & 1.95 \\
\hline $\mathrm{O}_{3}$ & 18.44 & 16.77 & 17.36 & 16.94 & 16.92 & 17.64 & 18.21 & 17.07 & 17.54 \\
\hline 0 & 21.32 & 14.21 & 11.76 & 21.65 & 22.18 & 20.59 & 18.92 & 21.19 & 21.73 \\
\hline (C) & b.d. & b.d. & 0.28 & b.d. & b.d. & b.d. & b.d. & b.d. & b.d. \\
\hline $8 \mathrm{C}$ & 7.71 & 12.04 & 14.20 & 7.40 & 7.31 & 8.57 & 9.42 & 8.06 & 8.33 \\
\hline 80 & b.d. & b.d. & b.d. & b.d. & b.d. & b.d. & b.d. & b.d. & b.d. \\
\hline 0 & b.d. & b.d. & b. & b.d. & b.d. & b.d. & b.d. & b.d. & \\
\hline & 9.69 & 10.37 & 10.49 & 9.49 & 9.64 & 9.83 & 10.23 & 9.27 & 9.69 \\
\hline & 0.17 & b.d. & 0.60 & 1.49 & 1.23 & 0.30 & 0.61 & 0.89 & 0.33 \\
\hline$=\mathrm{Cl}$ & 0.04 & 0.00 & 0.14 & 0.34 & 0.28 & 0.07 & 0.14 & 0.20 & 0.07 \\
\hline tal & 93.85 & 92.49 & 94.12 & 92.47 & 92.57 & 92.63 & 93.85 & 92.27 & 94.90 \\
\hline i $a p f i$ & 5.45 & 5.689 & 5.667 & 5.429 & 5.383 & 5.381 & 5.372 & 5.482 & 5.493 \\
\hline & 2.548 & 2.311 & 2.333 & 2.571 & 2.617 & 2.619 & 2.628 & 2.518 & 2.507 \\
\hline & 0.855 & 0.724 & 0.719 & 0.471 & 0.594 & 0.589 & 0.715 & 95 & 0.700 \\
\hline & 2.791 & 1.825 & 1.467 & 2.905 & 0.986 & & 2.464 & & 2.819 \\
\hline Mn & 0.000 & 0.000 & 0.035 & 0.000 & 0,000 & 0.000 & 0,000 & 0.000 & 0.000 \\
\hline & & 2.7 & 3.158 & & & & & & 1.927 \\
\hline & 0.205 & 0.237 & 0.178 & 0.243 & 0.259 & 0.233 & 0.247 & 0.201 & 0.228 \\
\hline & 1.935 & 2.031 & 1.996 & 1.943 & 1.980 & 1.995 & 2.032 & 1.889 & 1.9 \\
\hline & 0.000 & 0.210 & 0.152 & 0.405 & 0.336 & 0.081 & 0.161 & 0.241 & 0.087 \\
\hline . & 15.632 & 15.572 & 15.704 & 15.900 & 15.910 & 15.770 & 15.806 & 15.775 & 15.678 \\
\hline & 0.39 & 0.60 & 0.68 & 0.38 & 0.38 & 0.43 & 0.47 & 0.40 & 0.41 \\
\hline
\end{tabular}

The samples were analyzed at the Advanced Analytical Centre, James Cook University, by energy-dispersion spectrometry using a JXA-840A electron microprobe and Zaph corrections. Minerals and oxides were used as standards. The rock types are as follows: 404 : unmetasomatized muscovite-biotite schist, 430.26 and 430.25: abitites, 430.4 : biotite-rich schist with andalusite, 725.3 : biotite-rich schist

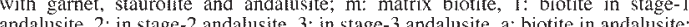
b.d. below detection limits. The detection limits for chlorine was generally around 0.14 w $\%$. The number of a. The detection on 22 atoms of oxyen. not $\mathrm{Cl}$ enrichment unless $f(\mathrm{HCl}) / f\left(\mathrm{H}_{2} \mathrm{O}\right)$ also was sufficiently high in the brines (Munoz \& Swenson 1981).

Pegmatites generated by anatexis of the Soldiers Cap Group are a possible source of acidic fluids, as associated sillimanite is quite abundant in the higher-grade rocks around the Cannington and Osborne mines at the southern extremity of the Eastern Fold Belt (Mark et al. 1998, Rubenach et al. 2001). Such sillimanite is commonly associated with S-type granite, those formed at the expense of metasedimentary protoliths, and most probably formed by base-ion leaching by acidic fluids (Vernon 1979, McLellan et al. 2002). However, the $\mathrm{Cl}$ content of biotite accompanying sillimanite at the Osborne mine is low (Adshead 1995, M.J. Rubenach, unpubl. data), so it is by no means certain that fluids derived from crystallizing pegmatites below the Snake Creek Anticline supplied the $\mathrm{HCl}$-bearing fluids for $\mathrm{Cl}$ enrichment in biotite.

Despite the very low values in area 1 , there is a connection between albitization and $\mathrm{Cl}$ enrichment in biotite in that the highest values (taking into account the $\mathrm{Mg}-\mathrm{Cl}$ avoidance) are in biotite-rich schists. Although the $\mathrm{Cl}$ average for biotite from unmetasomatized muscovite schists is $0.21 \mathrm{wt} \%$ (Table 3 ), the high values are from samples of muscovite schist located close to albitite. It is also significant that $\mathrm{Cl}$ values up to $0.8 \%$ occur in biotite within early-growth andalusite, and that late albite accompanies chlorine-rich biotite in the matrix of some biotite-rich schists. There may thus be a more subtle connection between albitization and $\mathrm{Cl}$ enrichment.

TABLE 3. AVERAGE CONCENTRATIONS OF Cl AND
AVERAGE Mgth OF BIOTITE IN ALBITITES
AND BIOTITE-RICH SCHIST FROM THE SNAKE CREK ANTICLINE,
MOUNT ISA INLIER, AUSTRALIA
$\mathrm{Cl}$ concentrations below the limits of detection were treated as zero in the
calculations. 


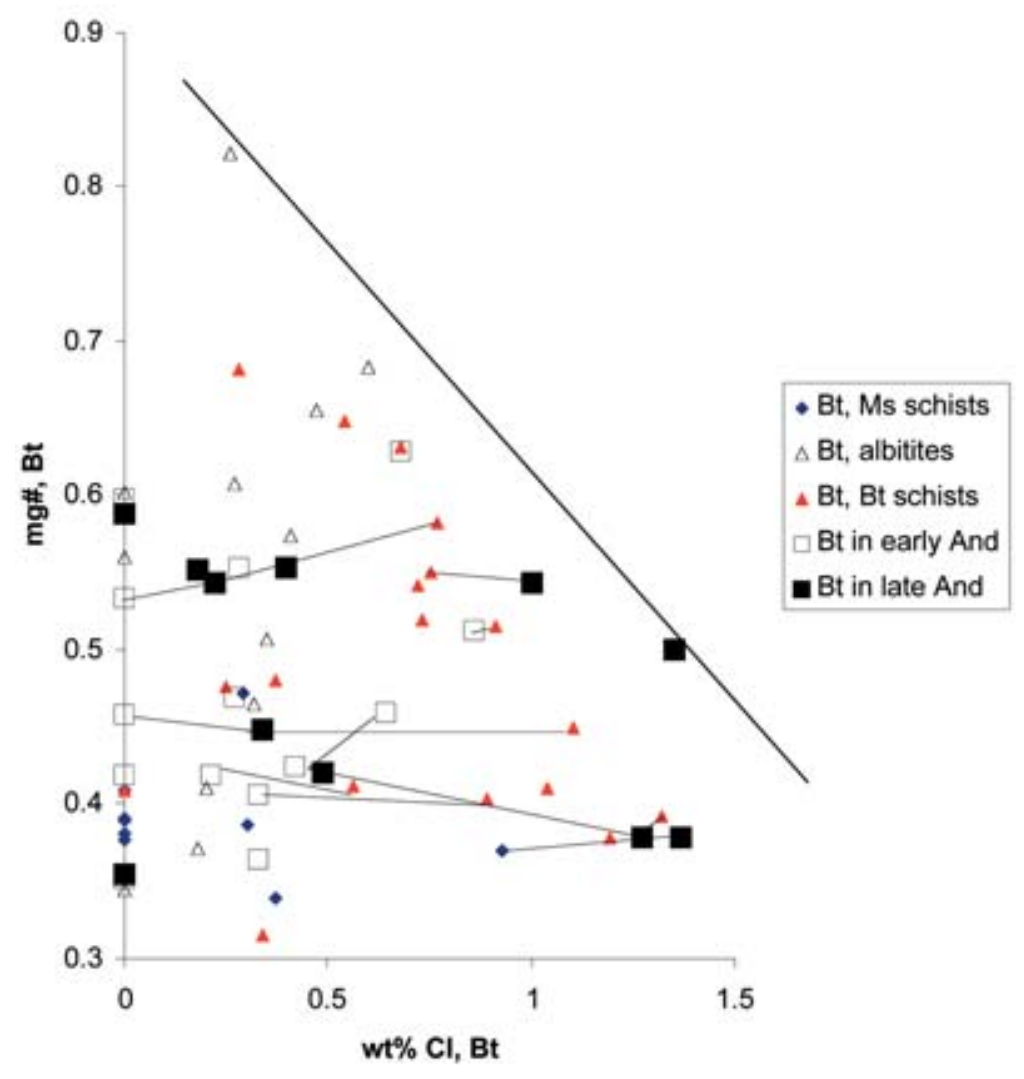

FIG. 9. Plot of $\mathrm{Mg \#}$ against wt $\% \mathrm{Cl}$ for biotite in the matrix and as inclusions in early- and late-stage andalusite. A line indicates the maximum $\mathrm{Cl}$ in biotite in rocks from Snake Creek, and reflects $\mathrm{Mg}-\mathrm{Cl}$ avoidance. Symbols connected with lines indicate, for particular samples, biotite compositions in the matrix and as inclusions in various stages of andalusite growth. $\mathrm{Cl}$ values below the theoretical detection-limit $(0.14 \mathrm{wt} \%)$ are plotted as zero.

The most important reaction to account for the albitization of muscovite schists, muscovite and quartz being replaced by albite, is:

$$
\begin{aligned}
& \mathrm{KAl}_{3} \mathrm{Si}_{3} \mathrm{O}_{10}(\mathrm{OH})_{2}+3 \mathrm{Na}^{+}+6 \mathrm{SiO}_{2} \\
& =3 \mathrm{NaAlSi}_{3} \mathrm{O}_{8}+2 \mathrm{H}^{+}+\mathrm{K}^{+}
\end{aligned}
$$

This reaction is based on constant $\mathrm{Al}$, support for which is provided by isocon diagrams plotted for albitites and corresponding schist protoliths (Oliver et al., in press). Note that $\mathrm{H}^{+}$is released in the reaction, and I contend that $\mathrm{Cl}$ enrichment in biotite is connected with $\mathrm{HCl}$ that was produced during the albitization reactions. Where the flux of externally derived fluid was high (during peak albitization), only limited interaction occurred with the muscovite schists. The resulting $\mathrm{H}^{+}$was thus easily diluted and removed from the system. In contrast, dur- ing periods of low flux, reaction between the schists and $\mathrm{NaCl}$ in the fluid was more complete, so that $f(\mathrm{HCl}) /$ $f\left(\mathrm{H}_{2} \mathrm{O}\right)$ increased, and biotite became enriched in $\mathrm{Cl}$. Changes during deformation in the activities of $\mathrm{Na}, \mathrm{K}$ and $\mathrm{H}$ due to grain-size reduction and surface ion-exchange (Winsch 1975, Wintsch \& Knipe 1983) may have been additional influences on the local equilibria and kinetics of reactions.

Microstructures indicate that albitization and biotite alteration occurred over a protracted period, from $D_{1}$ to post- $\mathrm{D}_{3}$, and there likely was a significant variation in fluid flux over this period. This model can explain the following points:

1. Based on structural and microstructural observations, albitization peaked during $\mathrm{D}_{1}$, corresponding with the largest changes in $\mathrm{Mg \#}$ of the biotite. However, albitization continued with less intensity to until after 

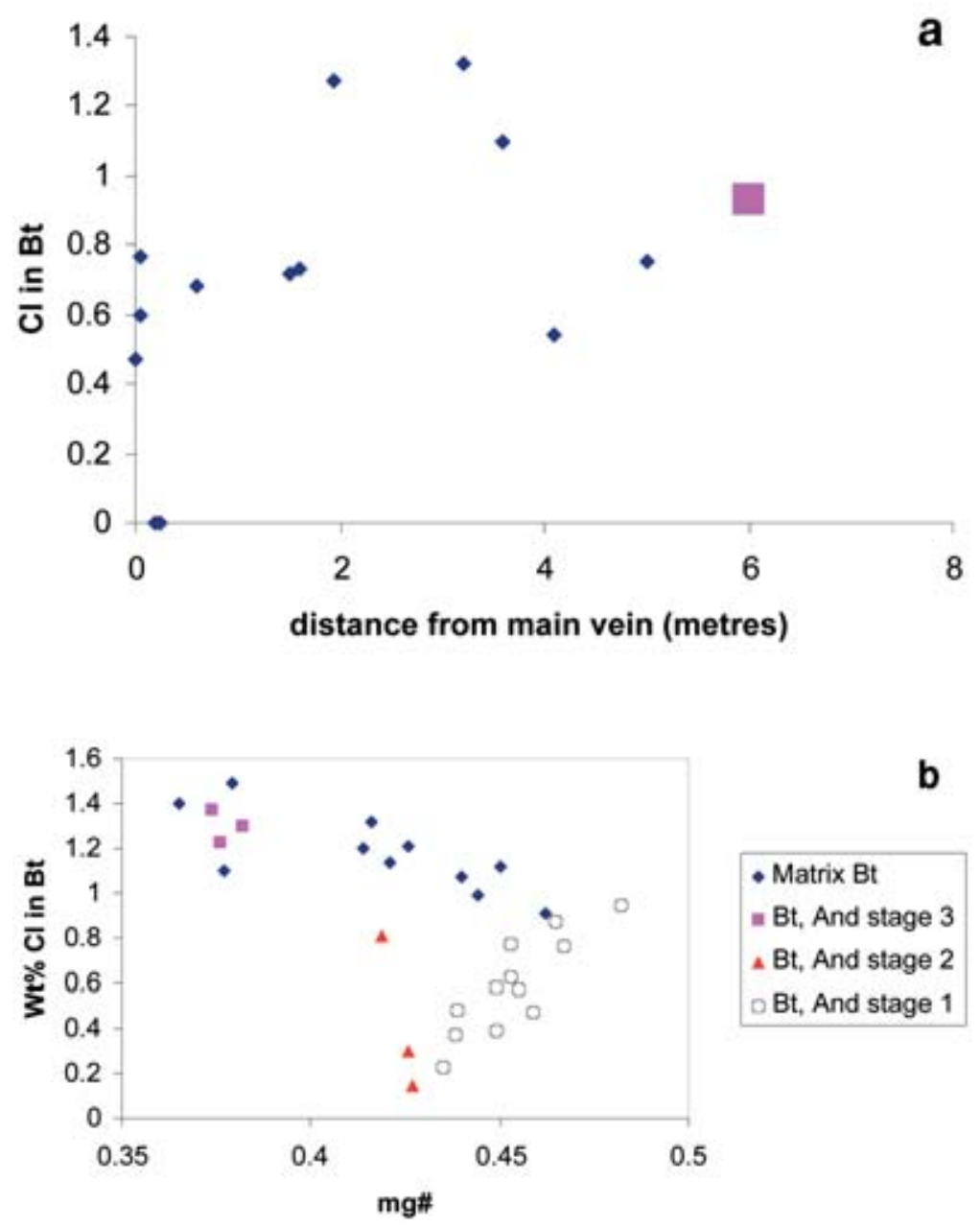

FIG. 10. Plots of composition of matrix biotite against distance from the main albitite at location 430 (Fig. 3). Values for unmetasomatized muscovite schist are plotted for comparison, at an arbitrary distance of 7.5 meters. Symbols are as follows: squares: albitites, diamonds: biotite-rich schists, triangles: unmetasomatized muscovite schists. (a) Mg\# for biotite versus distance, and (b) $\mathrm{wt} \% \mathrm{Cl}$ in biotite versus distance.

the $\mathrm{D}_{3}$ episode. It was during the waning stages of albitization that build-up of $\mathrm{HCl}$ could occur, so that maximum enrichment of $\mathrm{Cl}$ in biotite occurred relatively late in the albitization history.

2. The variation in $\mathrm{Cl}$ in matrix biotite in the different areas of albitization can be explained in terms of variations in the fluid flux. In area 1, for example, the flux was high during albitization and ceased abruptly, so that no build-up of $\mathrm{HCl}$ could take place, resulting in $\mathrm{Cl}$ being below detection in biotite in all lithologies.

3 . In area 2 , the $\mathrm{Cl}$ content of biotite in the matrix of albitites and biotite-rich schists was close to the maximum line, except for some shear-zone albitites with over
95\% albite, which have very low $\mathrm{Cl}$ contents. Since the albitites formed relatively early when the fluid flux was high, the $\mathrm{Cl}$ in biotite was initially low and would have remained so in any lithology that was relatively impermeable late in the history, when $f(\mathrm{HCl})$ peaked. The albitites seem to have been relatively impermeable later in the metasomatic history.

4. As a generalization, the $\mathrm{Cl}$ content of biotite increased in inclusions in the following order: early andalusite, late andalusite, matrix, most likely owing to increasing $f(\mathrm{HCl}) / f\left(\mathrm{H}_{2} \mathrm{O}\right)$ corresponding to waning infiltration of fluid. 


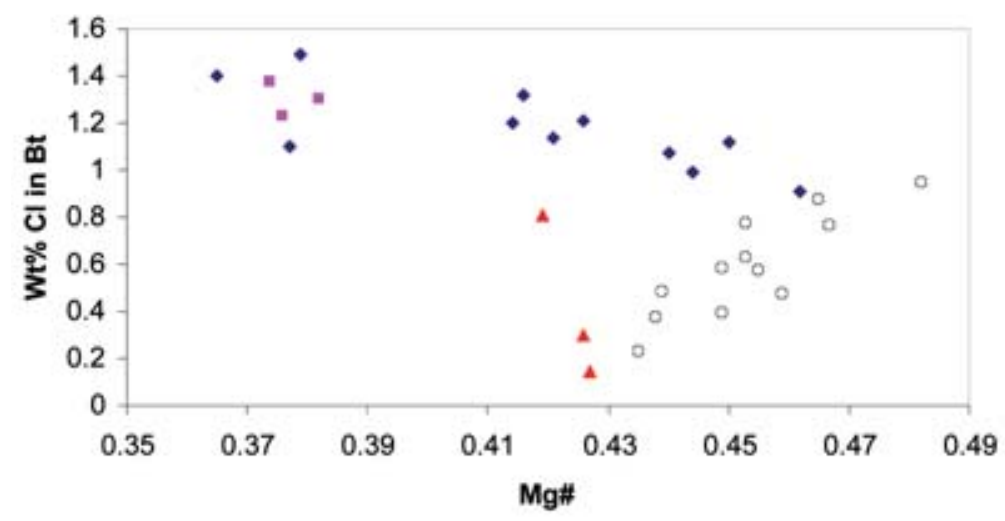

FIG. 11. Plot of $\mathrm{Cl}$ versus $\mathrm{Mg \#}$ for biotite in the matrix and as inclusions in andalusite, sample 430.4 (Figs. 7, 8). Symbols are as follows: diamonds: matrix biotite, squares: biotite inclusions in stage- 3 andalusite, triangles: biotite inclusions in stage- 2 andalusite, circles: biotite inclusions in stage-1 andalusite.

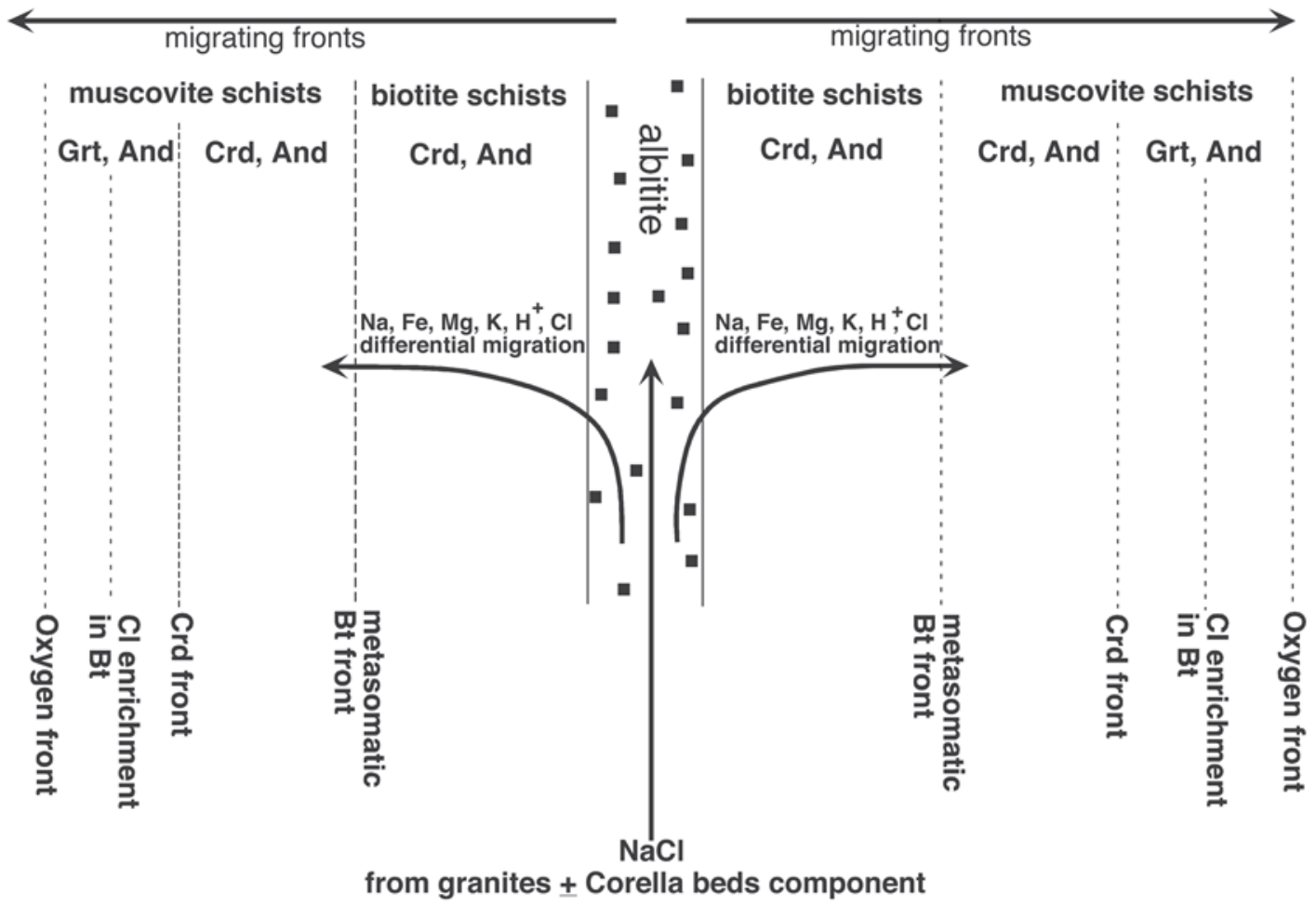

FIG. 12. Overall model depicting albitization, biotite alteration, and $\mathrm{Cl}$ enrichment in biotite. Albitization of schists along shear zones led to depletion of $\mathrm{K}, \mathrm{Fe}$, and $\mathrm{Mg}$. Biotite-rich schists formed adjacent to albite-enriched shear-zones by addition of $\mathrm{Mg}$, $\mathrm{Na}$ and, in places, Fe. Differential movement of $\mathrm{Mg}$ and Fe early in the metamorphic and metasomatic history led to a spatial association of cordierite and albitites. The hydrogen ion, released during the albitization of muscovite, was only allowed to increase during periods of reduced flux of fluid, and led to $\mathrm{Cl}$ enrichment in biotite. The oxygen front refers to the limits of resetting of oxygen isotopes by the metasomatizing fluids. 
The essential features of the proposed model for albitization and associated alteration and $\mathrm{Cl}$ enrichment of biotite are summarized in Figure 12. Infiltration of external fluids was initiated in the $\mathrm{D}_{1}$ event, producing albitites, in part structurally controlled by shear zones. Iron and $\mathrm{Mg}$ were removed during albitization, and, along with $\mathrm{Na}$, were added to adjacent schists to form the biotite-rich metasomatic rocks. Both $\mathrm{Fe}$ and $\mathrm{Mg}$ moved differentially, so that $\mathrm{Mg} \#$ varies across the biotite-rich schists. It is uncertain whether any $\mathrm{Fe}$ or $\mathrm{Mg}$ was also added from the external fluids. The $\mathrm{HCl}$ formed as a by-product during the albitization of muscovite, and during the waning stages of albitization (particularly during $\left.\mathrm{D}_{3}\right), f(\mathrm{HCl}) / f\left(\mathrm{H}_{2} \mathrm{O}\right)$ increased, such that $\mathrm{Cl}$ was partitioned into biotite.

Sedimentary rocks in shallow marine and continental margin environments may provide the high-salinity fluids during metamorphism (Yardley \& Graham 2002). The source of such fluids is unlikely to be in the host Llewellyn Creek Formation, the original sedimentary rocks being of turbidite origin. However, the Corella beds (or Mary Kathleen Group in general) were originally dolomitic sediments that commonly are evaporitic, as evidenced by the abundance of marialite-rich scapolite (Oliver 1995). Dissolution of evaporites to provide brines was considered by Oliver et al. (1994) to explain the widespread occurrence of albitite in the Mary Kathleen Group, but was subsequently rejected as a major source, as stable isotope data suggest equilibration with magmatic fluids (e.g., Oliver et al., in press). The Snake Creek albitites have $\delta^{18} \mathrm{O}$ values in the range 7.1-10.4\%. For a temperature of albitization of $c a .580 \mathrm{C}$, these values are more consistent with a magmatic origin than brines equilibrated with marble and calc-silicate rocks (M.J. Rubenach, unpubl. data). Another possibility is for essentially magmatic fluids to have contained a component derived from the dissolution of salt-rich beds into the magma prior to its crystallization and to the exsolution of a fluid phase (Oliver et al., in press).

\section{ACKNOWLEDGEMENTS}

Numerous discussions on albitization, fluids, structural geology and metamorphism with the following colleagues and Ph.D. students at the School of Earth Sciences, James Cook University, and in the Cooperative Research Centre in Predictive Mineral Discoveries are gratefully acknowledged: Nick Oliver, Tim Bell, Tom Blenkinsop, Tim Baker, Pat Williams, James Cleverly, Damien Foster, Bin Fu, Kathryn Lewthwaite, Geordie Mark, Roger Mustard and Sayab Mohammad. Sayab is also thanked for preparing some critical oriented thin sections. Discussions with Bob Wintsch concerning albitization processes were of considerable help in developing a coherent model relating $\mathrm{Cl}$ enrichment to albitization. Electron-microprobe analyses were carried out at the Advanced Analytical Centre, James Cook
University, and Kevin Blake is thanked for his assistance. I thank the referees Marc St-Onge, Mary Sanborn-Barrie and Doug Tinkham for their numerous suggestions for improvement to the manuscript.

I acknowledge Dugald Carmichael's 1969 paper on the mechanisms of prograde metamorphic reactions. I read this paper while searching for research directions in the mid-1970s, being an igneous petrologist appointed to teach metamorphic petrology at James Cook University. Dugald's paper allowed me to make sense of many reaction microstructures I was observing, and, along with papers concerning timing of metamorphism relative to deformation history, inspired me to maintain a central focus on microstructures in subsequent research on metamorphism. It is my pleasure to dedicate this paper to him.

\section{REFERENCES}

Adshead, N.D. (1995): Geology, Alteration and Geochemistry of the Osborne Cu-Au Deposit, Cloncurry District, NW Queensland. Ph.D. thesis, James Cook Univ., Townsville, Australia.

Voulgaris, P. \& Muscio, V.N. (1998): Osborne copper-gold deposit. In Geology of Australian and Papua New Guinean Mineral Deposits (D.A. Berkman \& D.H. MacKenzie, eds.). Austral. Inst. Mining Metall. 222, 793799.

BELL, T.H. (1986): Foliation development and refraction in metamorphic rocks: reactivation of earlier foliations and decrenulation due to shifting patterns of deformation partitioning. J. Metamorph. Geol. 4, 421-444.

\& HAYWARD, N. (1991): Episodic metamorphic reactions during orogenesis: the control of deformation partitioning on reaction sites and reaction duration. $J$. Metamorph. Geol. 9, 619-640.

\& RUBENACH, M.J. (1983): Sequential porphyroblast growth and crenulation cleavage development during progressive deformation. Tectonophysics 92, 171-194.

Blake, D. H. \& Stewart, A.J. (1992): Stratigraphic and tectonic framework, Mount Isa Inlier. In Detailed Studies of the Mount Isa Inlier (A.J. Stewart \& D.H. Blake, eds.). Aust. Geol. Surv. Org., Bull. 243, 1-11.

CARMiChaEL, D.M. (1969): On the mechanisms of prograde metamorphic reactions in quartz-bearing pelitic rocks. Contrib. Mineral. Petrol. 20, 244-267.

DE Jong, G. \& Williams, P.J. (1995): Giant metasomatic system formed during exhumation of mid-crustal Proterozoic rocks in the vicinity of the Cloncurry Fault, northwest Queensland. Aust. J. Earth Sci. 42, 281-290.

Foster, D. \& Rubenach, M.J. (2001): High radiogenic heatproducing granites and metamorphism - an example from the western Mount Isa Inlier, Australia: comment. Geology 28, 671 . 
Gautier, L., Hall, G., Stein, H. \& SchaltegGer, U. (2001): The Osborne Deposit, Cloncurry District: a $1595 \mathrm{Ma} \mathrm{Cu}-$ $\mathrm{Au}$ skarn deposit. In A Hydrothermal Odyssey (P.J. Williams, ed.). Economic Geology Research Unit, Contrib. 59, 58-59 (abstr.).

Giles, D. \& NutMan A.P. (2002): SHRIMP U-Pb monazite dating of 1600-1580 Ma amphibolite facies metamorphism in the southeastern Mt Isa Block, Australia. Aust. J. Earth Sci. 49, 455-465.

Goleby, B.R., Drummond, B., MacCready, T. \& Goncharov, A. (1996): The Mount Isa deep seismic transect. In MIC'96, New Developments in Metallogenic Research: the McArthur, Mount Isa, Cloncurry Mineral Province (T. Baker, J.F. Rotherham, G. Mark \& P.J. Williams, eds.). James Cook University Economic Geology Research Unit, Contrib. 55, 51-55.

KretZ, R. (1983): Symbols for rock-forming minerals. Am. Mineral. 68, 277-279.

LoOsVELD, R.J.H. (1989): The synchronism of crustal thickening and high T/low P metamorphism in the Mount Isa Inlier, Australia. 1. An example, the central Soldiers Cap Group. Tectonophysics 158, 173-190.

Mark, G., Darvall, M. , Tolman, J., Foster, G.R.W., Williams, P.J. \& Pollard, P.J. (1999): Magmas and regional $\mathrm{Na}-\mathrm{Ca}$ alteration, Cloncurry district, Australia. In Mineral Deposits: Processes to Processing (C.J. Stanley et al., eds.). Balkema, Rotterdam, The Netherlands (385-388).

Phillips, G.N. \& Pollard, P.J. (1998): Highly selective partial melting of pelitic gneiss at Cannington, Cloncurry district, Queensland. Aust. J. Earth Sci. 45, 169175 .

Mclelland, J., Morrison, J., Selleck, B., Cunningham, B., OLSON, C. \& SCHMIDT, K. (2002): Hydrothermal alteration of late- to post-tectonic Lyon Mountain Granitic Gneiss, Adirondack Mountains, New York: origin of quartzsillimanite segregations, quartz-albite lithologies, and associated Kiruna-type low-Ti Fe-oxide deposits. $J$. Metamorph. Geol. 20, 175-190.

MunOZ, J.L. (1984): F-OH and Cl-OH exchange in micas with applications to hydrothermal ore deposits. In Micas (S.W. Bailey, ed.). Rev. Mineral. 13, 469-494.

(1992): Calculation of $\mathrm{HF}$ and $\mathrm{HCl}$ fugacities from biotite compositions: revised equations. Geol. Soc. Am., Abstr. Programs 24, A221.

\& Swenson, A. (1981): Chloride-hydroxyl exchange in biotite and estimation of relative $\mathrm{HCl} / \mathrm{HF}$ activities in hydrothermal fluids. Econ. Geol. 76, 2212-2221.

OLIVER, N.H.S. (1995): Hydrothermal history of the Mary Kathleen Fold Belt, Mt Isa Block, Queensland. Aust. J. Earth Sci. 42, 267-280.

Cartwright, I., Wall, V.J. \& Golding, S.D. (1993): The stable isotope signature of kilometre-scale fracture-dominated metamorphic fluid pathways, Mary Kathleen, Australia. J. Metamorph. Geol. 11, 705-720.

Mark, G., Cleverrly, J., Pollard, P.J., Fu, Bin, Marshall, L.J., Williams, P.J. \& BAKER, T. (2004): The role of sodic alteration in the genesis of iron oxide - copper - gold deposits, eastern Mt Isa Block, Australia. Econ. Geol. 99, 1145-1176.

Rawling, T.J., Cartwright, I. \& Pearson, P.J. (1994): High temperature fluid-rock interaction and scapolitization in a large extension-related hydrothermal system, Mary Kathleen, Australia. J. Petrol. 35, 14551491

WALL, V.J. \& CARTWRIGHT, I. (1992): Internal controls of fluid compositions in amphibolite-facies scapolitic calc-silicates, Mary Kathleen, Australia. Contrib. Mineral. Petrol. 111, 94-112.

Page, R.W. \& Sun, S.-S. (1998): Aspects of geochronology and crustal evolution in the Eastern Fold Belt, Mount Isa Inlier. Aust. J. Earth Sci. 45, 343-361.

ReINHARDT, J. \& RUBENACH, M.J. (1989): Temperature-time relationships across metamorphic zones: evidence from porphyroblast-matrix relationships in progressively deformed metapelites. Tectonophysics 158, 141-161.

Rubenach, M.J., Adshead, N.D., Oliver, N.H.S., Tullemans, F., Esser, D. \& Stein, H. (2001): The Osborne $\mathrm{Cu}-\mathrm{Au}$ deposit: geochronology and genesis of mineralization in relation to host albitite and ironstones. In A Hydrothermal Odyssey (P.J. Williams, ed.). Economic Geology Research Unit, Contrib. 59, 172-173 (abstr.).

\& BARKer, A.J. (1998): Metamorphic and metasomatic evolution of the Snake Creek Anticline, Eastern Succession, Mount Isa Inlier. Aust. J. Earth Sci. $\mathbf{4 5}$ 363-372.

\& Lewthwaite, K.A. (2002): Metasomatic albitites and related biotite-rich schists from a low-pressure polymetamorphic terrane, Snake Creek Anticline, Mount Isa Inlier, north-eastern Australia: microstructures and P-T-t paths. J. Metamorph. Geol. 20, 191-202.

VERNON, R.H. (1978): Porphyroblast-matrix microstructural relationships in deformed metamorphic rocks. Geol. Rundsch. 67, 288-305.

(1979): Formation of late sillimanite by hydrogen metasomatism (base-leaching) in some high-grade gneisses. Lithos 12, 143-152.

WiLLiams, P.J. (1998): Metalliferous economic geology of the Mt Isa Eastern Succession, Queensland. Aust. J. Earth Sci. 45, 329-341.

, Dong, Guoyi, Pollard, P.J., Perring, C.S., Ryan, C.G. \& MERnAGH, T.P. (1999): Fluid inclusion geochemistry of Cloncurry $(\mathrm{Fe})-\mathrm{Cu}-\mathrm{Au}$ deposits. In Mineral Deposits: Processes to Processing (C.J. Stanley, ed.). Balkema, Rotterdam, The Netherlands (111-114). 
WINTSCH, R.P. (1975): Feldspathization as a result of deformation. Geol. Soc. Am., Bull. 86, 35-38.

\& KNIPE, R.J. (1983): Growth of a zoned plagioclase porphyroblast in a mylonite. Geology 11, 360-363.

YARDLEY, B.W.D. \& GRAHAM, J.T. (2002): The origins of salinity in metamorphic fluids. Geofluids 2, 249-256.

Zhu, Chen \& SverJensky, D.A. (1991): Partitioning of F-Cl$\mathrm{OH}$ between minerals and hydrothermal fluids. Geochim. Cosmochim. Acta 55, 1837-1858
ZWART, H.J. (1960): Relations between folding and metamorphism in the central Pyrenees, and their chronological succession. Geol. Mijnbouw 39, 163-180.

Received October 17, 2003, revised manuscript accepted August 15, 2004. 